\title{
THE NEXUS BETWEEN SEA ICE AND POLAR EMISSIONS OF MARINE BIOGENIC AEROSOLS
}

\author{
Albert Gabric, Patricia Matral, Graham Jones, and Julia Middleton
}

\begin{abstract}
We examine the relationship between sea ice dynamics, phytoplankton biomass, and emissions of marine biogenic aerosols in both the Arctic and Southern Oceans.
\end{abstract}

M arine biogenic aerosol (MBA) plays an important role in the radiative budget of remote marine atmospheres by potentially shaping regional climate (McCoy et al. 2015). MBAs can influence cloud microphysical properties as cloud condensation nuclei (CCN), affecting cloud albedo and lifetime. However, despite three decades of research, the impacts of aerosol-cloud interactions on climate are still poorly understood (Ayers and Cainey 2007; Carslaw et al. 2013). MBAs are formed through the atmospheric oxidation of volatile precursor compounds, such as dimethylsulfide (DMS), organohalogens [such as the halogen oxide radicals iodine oxide (IO) and bromine oxide ( $\mathrm{BrO})]$, and other organic

AFFILIATIONS: GABRIC-School of Environment, Griffith University, Nathan, Queensland, Australia; MATRAI-Bigelow Laboratory for Ocean Sciences, East Boothbay, Maine; JONESSouthern Cross University, Lismore, New South Wales, Australia; MIDDLETON-Woods Hole Oceanographic Institution, Woods Hole, Massachusetts

CORRESPONDING AUTHOR: A. Gabric, a.gabric@griffith.edu.au

The abstract for this article can be found in this issue, following the table of contents.

DOI:10.II75/BAMS-D-16-0254.I

In final form 27 June 2017

(O)2018 American Meteorological Society

For information regarding reuse of this content and general copyright

information, consult the AMS Copyright Policy. compounds, and are also directly injected as primary aerosols (Carpenter et al. 2003; Leck and Bigg 2005a; Orellana et al. 2011). These compounds either are synthesized by phytoplankton or are by-products of marine ecosystem processes (Carslaw et al. 2010; Liss et al. 2000). Thus, the sea-to-air flux of these aerosol precursor compounds and particles depends, in a complex fashion, on the structure and dynamics of the marine food web (Simó 2001). Observed MBA concentrations at high latitudes can be one to two orders of magnitude higher than those at low and midlatitudes (Chen et al. 2012), highlighting the importance of polar regions as sources of MBAs.

Polar sea ice constitutes the habitat for one of the largest ecosystems on Earth (Arrigo 2014). Icecovered seas host a rich tapestry of biological activity and produce a range of MBAs (Korhonen et al. 2008). In the high Arctic, airborne marine gels with unique physicochemical characteristics originate from organics produced by ice algae or phytoplankton and appear to dominate the available CCN number population during the summer season (Karl et al. 2013; Orellana et al. 2011). Sea ice not only affects ocean-atmosphere interactions by providing a physical barrier to energy and gaseous exchange (Parmentier et al. 2013) but also shapes the polar marine food web. It is a habitat for ice algae (Gradinger 2009) and underice algal communities (Arrigo 2014), influencing the phenology of pelagic blooms that occur as ice retreats 


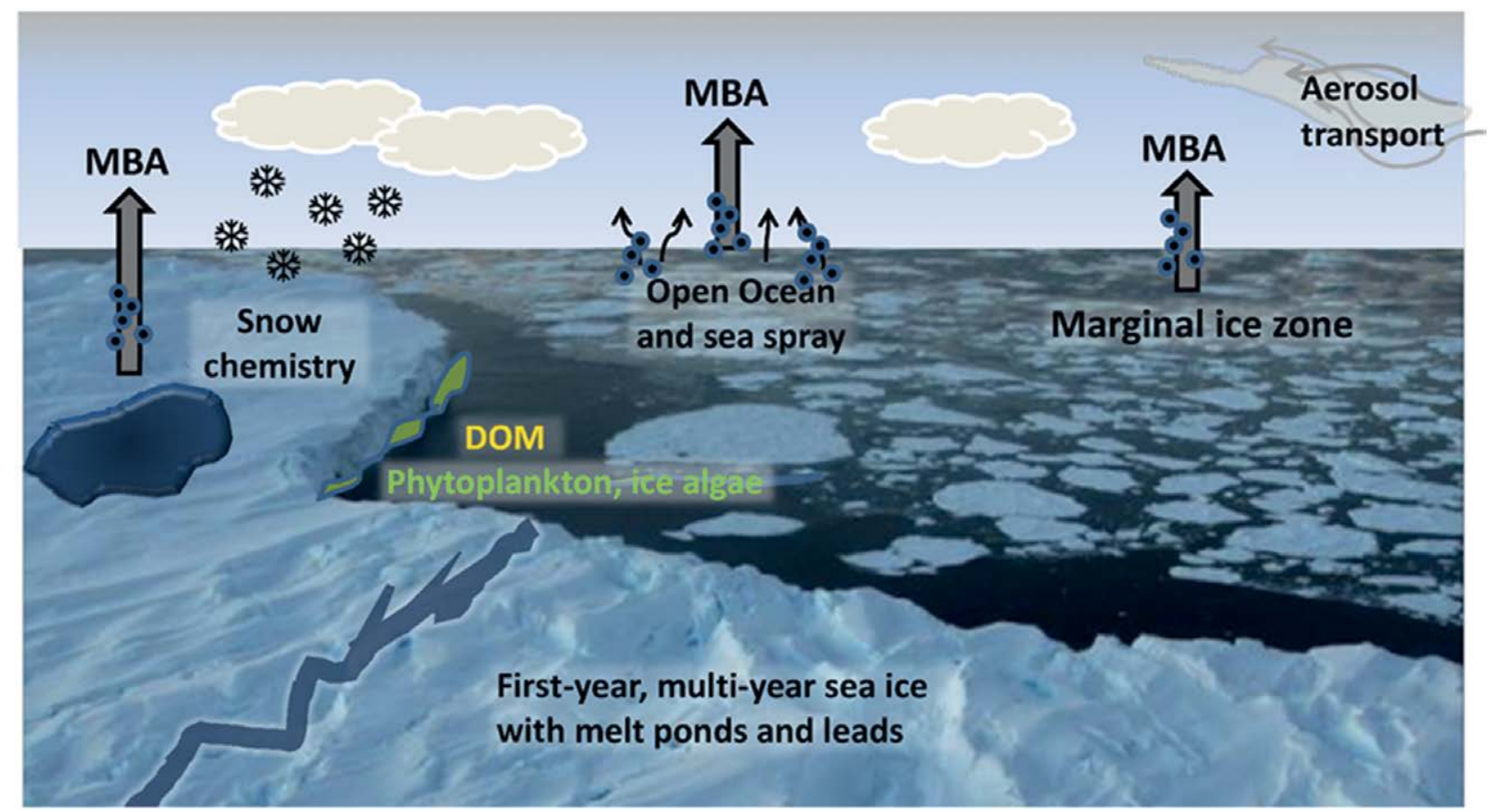

FıG. I. Biogeochemical processes involved in the production of MBAs in the polar oceans.

(Arrigo et al. 2008a; Gradinger 2009; Heide-Jørgensen et al. 2007) and consequently also impacting higher trophic levels (Leu et al. 2011; Saba et al. 2014). In the Southern Ocean (SO), simulated sea ice primary production (PP) can constitute $12 \%$ of total annual $\mathrm{PP}$ in the seasonal sea ice zone (SIZ), extending from the permanent ice zone to the boundary where winter sea ice extent is at a maximum, which corresponds to approximately $1 \%$ of annual PP in the SO (Saenz and Arrigo 2014). Over 50\% of marine PP in the central Arctic covered by perennial ice is attributed to ice algae (Gosselin et al. 1997), while on Arctic shelf seas, the percentage of annual PP by ice algae is estimated to be between $4 \%$ and 25\% (Legendre et al. 1992; Leu et al. 2011). However, these estimates of Arctic PP are problematic because of ongoing declines in sea ice extent (SIE) and the presence of massive under-ice algal blooms (Arrigo et al. 2012), which are invisible to satellite sensors.

Among ice-covered oceans, the Arctic is experiencing the greatest change, sea ice having decreased by about $40 \%$ in the last three decades (Stroeve et al. 2007) though modulated by large interannual and subdecadal variability (Parkinson and Comiso 2013; Simmonds 2015). First-year ice is rapidly replacing multiyear ice, and projections suggest that the SIZ might cover the entire Arctic Ocean by the 2020s (Overland and Wang 2013). This loss of perennial sea ice will dramatically increase the amplitude of the seasonal cycle of sea surface temperature and summer stratification of the water column in the Arctic Ocean (Carton et al. 2015). The decline in SIE in the Arctic over the past decade (Serreze et al. 2007) has been related to a $22 \%$ increase in annual panArctic PP, likely due to an increased phytoplankton growing season with more available light (Arrigo et al. 2008b). By influencing both pelagic and ice algal primary production, sea ice appears to play a key role in determining MBA emissions in the Arctic seas (Becagli et al. 2016), with some studies suggesting that a significant increase in MBA production will result from the retreat of ice cover and concomitant increase in PP (Gabric et al. 2005; Ito and Kawamiya 2010). Alternatively, studies that take the effect of ocean acidification (OA) into account suggest that MBA production may decrease in the future (Six et al. 2013). However, it has also been suggested that increases in wind-induced sea spray (with or without organics) may increase with more open water (Browse et al. 2014). Conversely, in the Indian Ocean sector of the SO where sea ice is increasing, intense summer phytoplankton blooms in the SIZ have been observed, likely due to the influx of nutrient-laden freshwater derived from melting sea ice (Sabu et al. 2014).

Accurate estimation of how much the climate sensitivity is affected by MBA emissions will require a more complete understanding of the nexus between food-web responses to warming, changes in sea ice, and the subsequent impact on MBA sources. Here, we review the current knowledge of MBA sources 
and the relationship with sea ice; in particular, we investigate the temporal nexus between ice melt and emissions of aerosol precursors and primary particles. We examine these processes by analyzing satellite data on MBAs, sea ice extent and seasonal variability, and indicators of biological activity in the Arctic and Antarctic SIZ. In addition, we examine current and projected trends in sea ice and discuss the likely impact on future biogenic aerosol emissions and polar climate.

\section{SOURCES OF MARINE AEROSOL IN PO-}

LAR SEAS. Marine aerosols are derived from both primary and secondary processes (Fig. 1). Where winds are high, sea salt aerosols, with estimated global emissions of 2,000-10,000 $\mathrm{Tg} \mathrm{yr}^{-1}$ (when limited to diameters $<20 \mu \mathrm{m}$ ), are a major component of primary marine aerosol mass (O’Dowd et al. 1997) and likely to increase significantly as SIE diminishes with warming (Browse et al. 2014). DMS-derived sulfate is thought to be the key precursor to secondary marine aerosol mass over biologically productive regions (McCoy et al. 2015); however, other primary organic compounds-physically organized as marine microgels-appear to be important MBA sources in the Arctic (Leck and Bigg 2005a; Orellana et al. 2011).

Polluted air masses from North America and Eurasia during winter and early spring-the so-called Arctic haze (Sirois and Barrie 1999)-complicate characterization of the Arctic aerosol. However, aerosol optical depth (AOD) data-a satellite-derived metric related to the amount of aerosol in the atmosphere-show peaks later in summer coincident with phytoplankton blooms and high emissions of biogenic aerosol precursors, such as DMS, and primary aerosols of biogenic origin (Chang et al. 2011; Gabric et al. 2014; Leck and Bigg 2005b). Atmospheric DMS mixing ratios in the high Arctic occasionally reach 200-300 parts per trillion by volume during the phytoplankton growth period from May to September (Park et al. 2013).

In the SIZ, ice algae are known to be significant producers of DMS and its precursor compound dimethylsulfonioproprionate (DMSP; Kirst et al. 1993; Levasseur et al. 1994). During seasonal ice melt, ice algae can be released into the surrounding water, initiating under-ice or ice-edge phytoplankton blooms (Galindo et al. 2014; Stewart and Fritsen 2004). Koga et al. (2014) noted abrupt increases in atmospheric DMS concentrations in the SO SIZ while the ship was underway and crushing the sea ice, likely caused by DMS emissions from gaps in the ice made by the icebreaker. Similar patterns of MBA emissions have been reported for Arctic sea ice (Galindo et al. 2015; Levasseur 2013).

\section{RECENT TRENDS IN SEA ICE COVER. Arctic}

Ocean. Arctic near-surface air temperatures have warmed at almost twice the global average in recent decades, a phenomenon known as Arctic amplification (Serreze and Barry 2011). Arctic SIE at the end of the melt season in September (Fig. 2a) has declined sharply over the last 50 years (Stroeve et al. 2007). The strong warming over the Arctic Ocean during the past decade in autumn and winter is clearly associated with reduced SIE (IPCC 2013; Screen and Simmonds 2010). Such positive sea ice-temperature feedbacks in the Arctic increase the likelihood of further warming and sea ice loss and will affect ecosystems and MBA emissions during the twenty-first century (Struthers et al. 2011). In September 2016, Arctic SIE stood at $4.14 \times 10^{6} \mathrm{~km}^{2}$, which appears to have been the lowest extent of the year and is tied with 2007 as the second lowest extent on record (National Snow and Ice Data Center 2016). Decadal changes in Arctic minimum SIE are shown in Fig. 2b, with the eight lowest values occurring in the last eight years (Arndt et al. 2015). Interannual variability is high; for example, the summer of 2012 experienced exceptional sea ice melt with the lowest minimum extent recorded, while the succeeding summers of 2013 and 2014 experienced much less sea ice melt (Fig. 2b). The mean annual cycle in Arctic SIE is shown in Fig. 3a.

Multidecadal analysis of the satellite-derived data shows continued net decrease in multiyear ice coverage in the Arctic Ocean (Maslanik et al. 2011). The fraction of total SIE made up of multiyear sea ice in March decreased from about $75 \%$ in the mid-1980s to $45 \%$ in 2011, with losses extending into the central Arctic Ocean and adjacent to the Canadian Archipelago, areas where SIE was relatively stable prior to 2007. These changes in multiyear sea ice have clear impacts on $\mathrm{PP}$, with annual net primary production (NPP) increasing 30\% over the entire Arctic Ocean from 1998 to 2012, attributed to reduced SIE and a longer phytoplankton growing season (Arrigo and van Dijken 2015), as indicated earlier. Regional and spatial variability in NPP are also seen in the satellite record, with caveats on remote sensing in polar seas (Babin et al. 2015). In a modeling study of the Canadian Arctic, increased PP and double-bloom development were simulated in areas of sea ice retreat where nutrient supply is sufficient, and unchanged or reduced production was seen where nutrients are low or suppressed because of enhanced stratification (Steiner et al. 2015). 

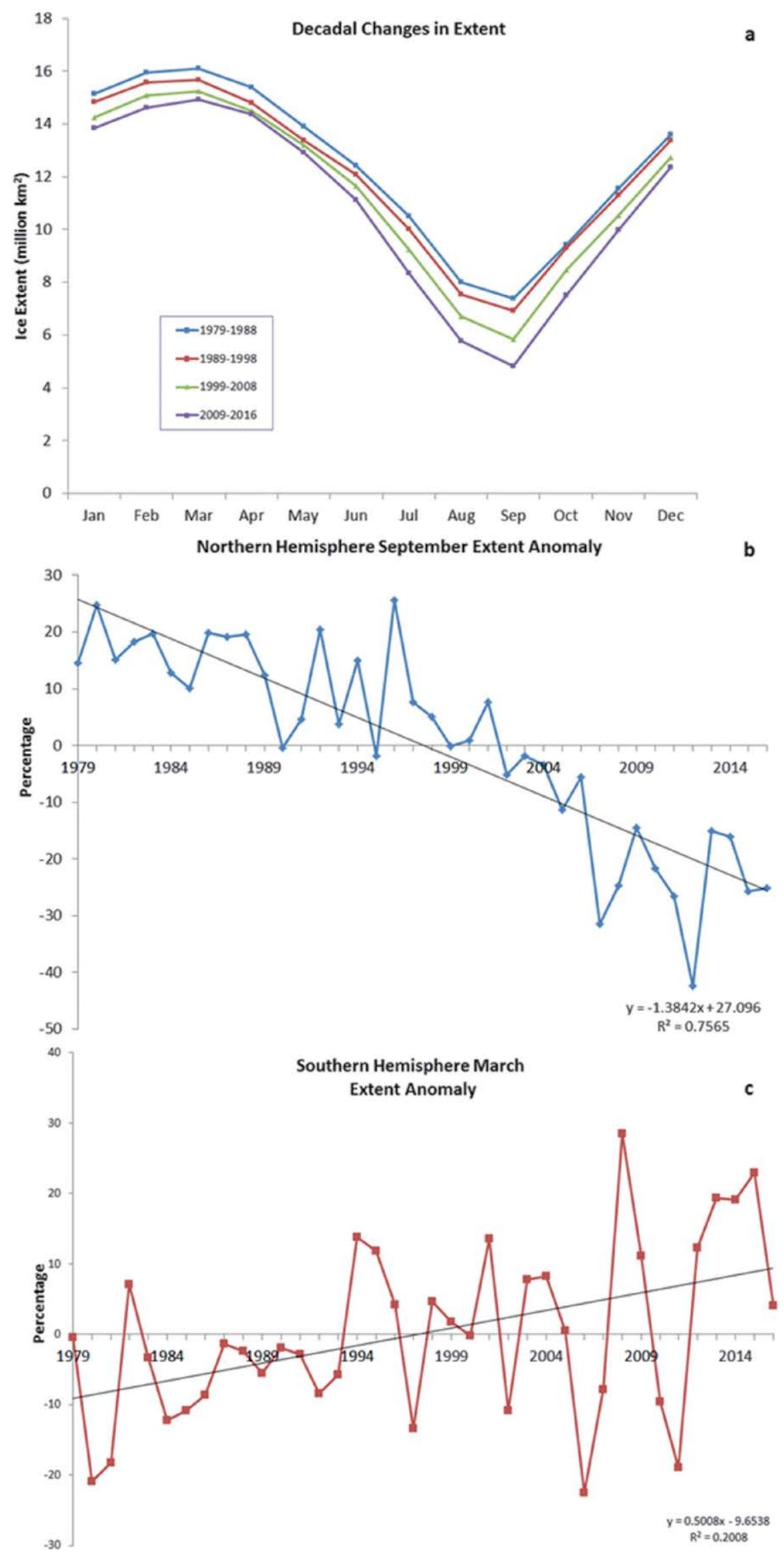

Antarctic and Southern

Ocean. In sharp contrast to the decreasing Arctic sea ice, Antarctic SIE has expanded since the late 1970s (Bintanja et al. 2015; Hobbs et al. 2016; Parkinson and Cavalieri 2012), with interesting interhemispheric comparisons given in Stammerjohn et al. (2012) and Simmonds (2015). Not only has Antarctic SIE countered the declining Arctic trend, but several new records were set in 2014, including record high monthly mean SIE from April to November. On 20 September 2014, a record large daily Antarctic SIE of $20.14 \times 10^{6} \mathrm{~km}^{2}$ occurred (Arndt et al. 2015). Massonnet et al. (2015) suggest that the primary cause for the 2014 record is anomalous thermodynamic sea ice growth near the ice edge in the Indian Ocean due to anomalous southerly advection of cold air there. A connection with increasing westerly winds has also been made by Fan et al. (2014).

A plot of the trend in the March SIE anomaly relative to the climatological mean for the 1981-2016 period is shown in Fig. 2c. There is a notable difference with the Northern Hemisphere (NH) shown in Fig. 2b, as the positive trend in annual-mean Antarctic SIE is now almost

4 Fig. 2. (a) Seasonal change in Arctic SIE by decade since 1979, (b) NH Sep SIE anomalies relative to the mean for period of 1981-2016, and (c) SH Mar SIE anomalies relative to the mean for period of 19812016 (data from the NSIDC: https://nsidc.org/). 
one-third of the magnitude of the NH annual-mean decrease (Simmonds 2015). The mean annual cycle in Antarctic SIE is shown in Fig. 3b. The general increase in Antarctic sea ice (especially in the Ross Sea) is qualitatively consistent with the prediction of a global atmospheric-ocean model of increasing sea ice around Antarctica under climate warming due to the stabilizing effects of increased snowfall on the SO (Zwally et al. 2002); however, this expansion is poorly simulated by more recent Coupled Model Intercomparison Project, phase 5 (CMIP5), models (Shu et al. 2015).

Another possible mechanism (also not well captured by climate models) is that meltwater from Antarctica's ice shelves accumulates in a cool and fresh surface layer shielding the surface ocean from the warmer deeper waters that are melting the ice shelves (Bintanja et al. 2013). An exception to this trend is the western Antarctic Peninsula (WAP), which has experienced a warming in winter of almost $7^{\circ} \mathrm{C}$ since 1950 , as well as the loss of ice shelves, the retreat of $87 \%$ of the marine glaciers, and significant decreases in winter sea ice duration (Bromwich et al. 2013; Ducklow et al. 2013; Stammerjohn et al. 2008). Interestingly, these changes have also led to recent increases in PP in the WAP (Moreau et al. 2015). Indeed, there is a general inconsistency between observed and modeled variability in Antarctic SIE, with the observed trends
Arctic Sea Ice Extent Climatology

a

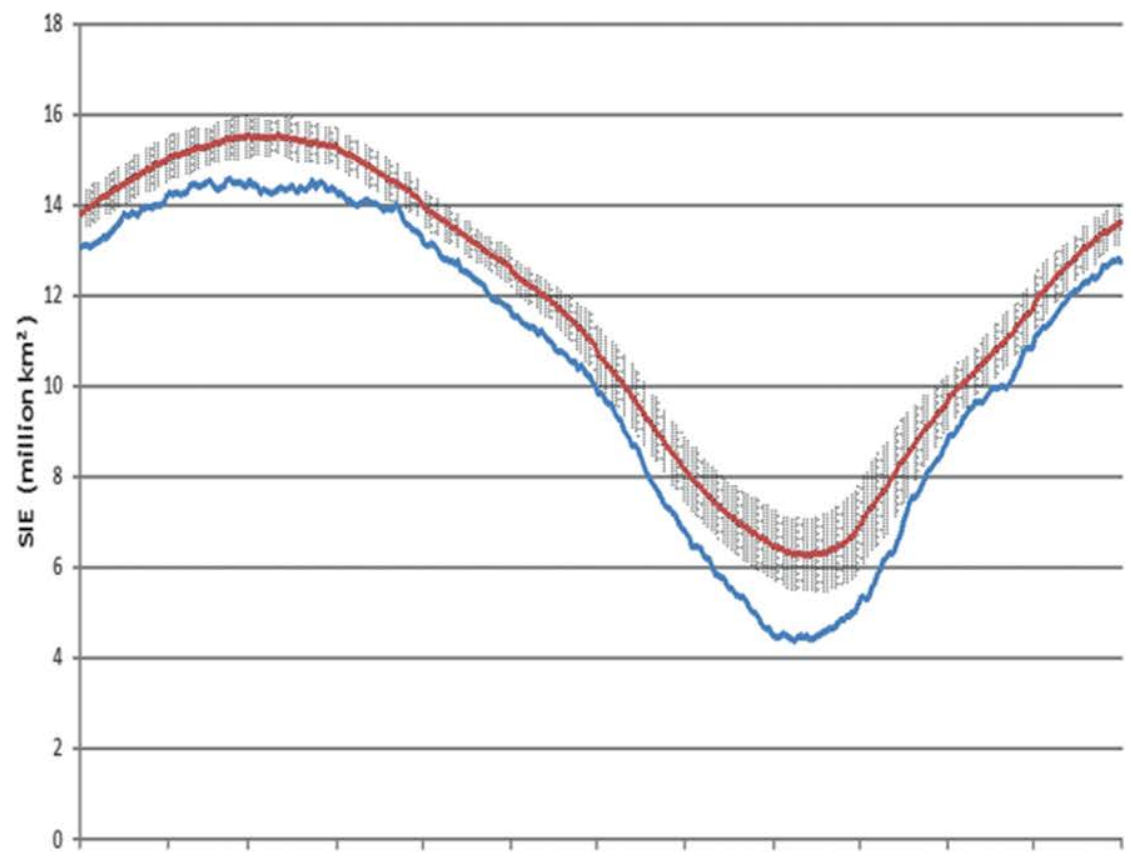

Antarctic Sea Ice Extent Climatology

-Mean(SO) for 1981-2000 —2015

b

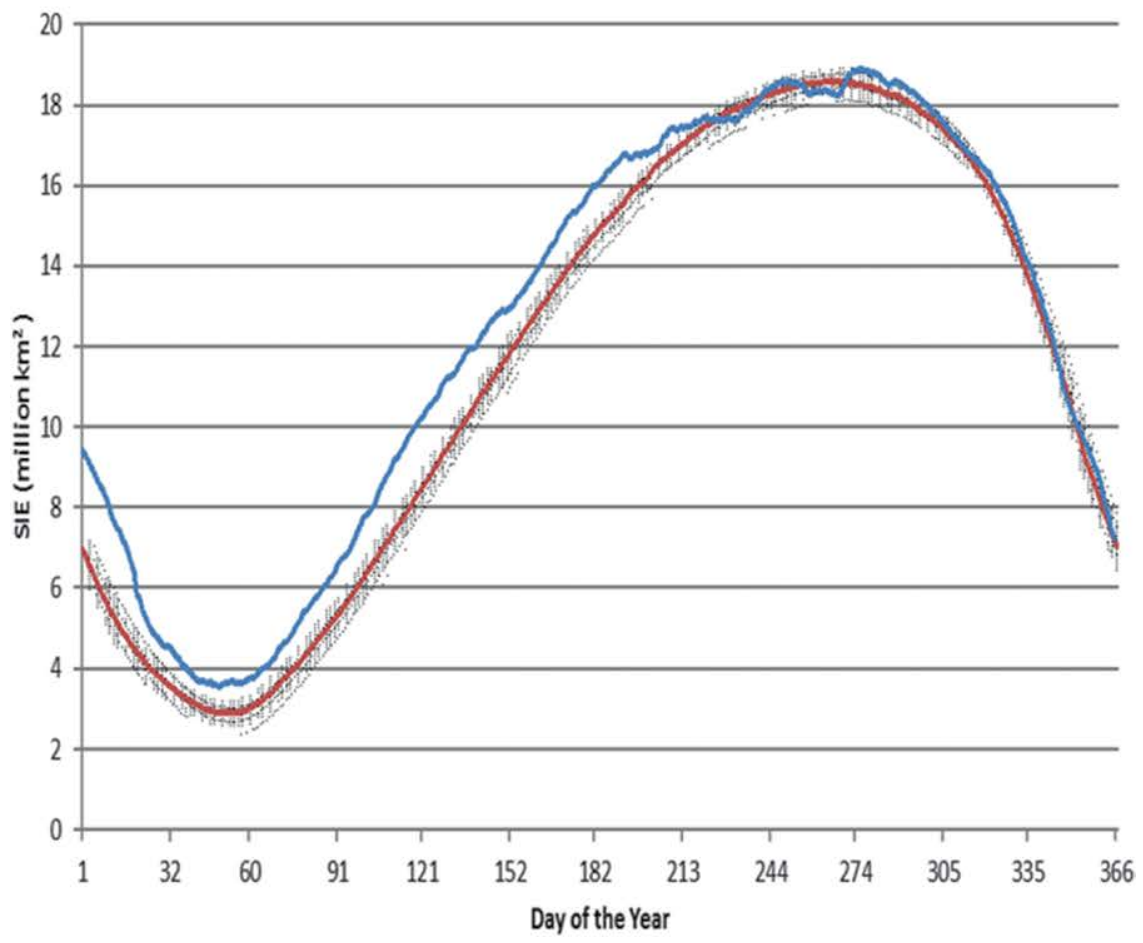

Fig. 3. The mean annual cycle in SIE for (a) Arctic and (b) Antarctic (data from the NSIDC: https://nsidc.org/).

since the mid-1960s being within the 5\%-95\% range of simulated trends (Gagné et al. 2015). 
DATA ANALYSIS. Historically, the cycle of sea ice formation and loss has been multiyear in the Arctic Ocean and annual in the Southern Ocean. Both systems have an annual cycle of sea ice formation consisting of the permanent open ocean, the marginal ice-edge zone (MIZ) that forms a dynamic boundary with the open ocean, and the SIZ covering the area that shifts from ice covered to ice free during a single year. The Arctic Ocean also has a multiyear pack ice zone whose spatial extent has decreased extensively over the past decades and is now located mostly north of the Canadian Archipelago and in the Beaufort Sea. Structurally, pack ice is oceanic sea ice occurring as free-floating floes ranging in diameter from centimeters to kilometers and thickness from millimeters to meters. Pack ice covers most of the SIZ in both polar oceans (Zwally et al. 1983). Fast ice is attached to the continent, often extending tens of kilometers from the land (Fedotov et al. 1998).

Field observations in the Arctic seasonal ice zone. Emission of MBAs and aerosol precursors from the ocean and ice and snow surfaces in the Arctic Ocean is closely related to seasonal ice retreat and regional location. Mechanisms have been proposed for a large increase in sea salt aerosol (Struthers et al. 2011), MBAs (Heintzenberg and Leck 2012; Leck and Bigg 2005a), and the source strength of MBAs (Orellana et al. 2011) and DMS (Leck and Persson 1996). Modeling suggests that an increase in sea salt emission in an ice-free Arctic would increase AOD over the Arctic by 23\% (Struthers et al. 2011) with a resulting increase in cloudiness (Liu et al. 2012). As summer sea ice extent decreases emission fluxes of sea salt, marine primary organic aerosols and DMS are likely to increase severalfold, with DMS emissions increasing the most (Browse et al. 2014).

Concentrations of aqueous DMS in open water and the MIZ in summer are highly variable, with median values being 1.4-3.6 nM (range: $0.5-22 \mathrm{nM}$; 1990-2008; Lundén et al. 2007; Tjernström et al. 2004, 2014) and maxima in ice-edge blooms around the Arctic (Gali and Simo 2010; Matrai et al. 2007; Matrai and Vernet 1997). Observed sea surface concentrations of DMS have been related to phytoplankton bloom stage (Gabric et al. 1999; Matrai and Vernet 1997), while simulated patterns have been negatively predicted by mean sea ice and nitrate concentration, with highest simulated aqueous DMS (up to $10.7 \mathrm{nM}$ ) in the SIZ (Humphries et al. 2012).

DMS and especially DMSP are present at high concentrations within sea ice, especially on the Arctic shelves, with concentrations up to 769 and 2,150 nM, respectively, reported for the vernal ice algal bloom in the Beaufort Sea first-year ice, or even 2,000 nM in the Canadian Archipelago at summer's end (Levasseur 2013) but only up to $29 \mathrm{nM}$ in multiyear ice in the Arctic central basin (Gosselin et al. 1997).

Atmospheric DMS concentrations are also highest during summer over the MIZ on the Atlantic side (1-30 $\mathrm{nmol} \mathrm{m}^{-3}$; Lundén et al. 2007) and the eastern Canadian Archipelago $\left(<1-24 \mathrm{nmol} \mathrm{m}^{-3}\right.$; Mungall et al. 2016) but decreasing in summer $\left(0.1-6 \mathrm{nmol} \mathrm{m}^{-3}\right)$ as the air mass is advected over the pack ice (Leck and Svensson 2015; Lundén et al. 2007); DMS concentrations were strongest at the atmospheric interface with ocean/ice and closest to the source regions. The 1994 Arctic Ocean section saw highest atmospheric DMS concentrations near the ice edge in the Pacific sector as well, which decreased as a function of increasing ice cover and low aqueous DMS at higher latitudes (Sharma et al. 1999). Once ventilated to the atmosphere, gas-particle nucleation and meteorological processes appear to account for the temporal variability observed in atmospheric DMS (Chang et al. 2011; Rempillo et al. 2011). Analysis of atmospheric DMS mixing ratios in the Atlantic sector of the Arctic Ocean showed high variability on time scales of days, with highest concentrations during the phytoplankton growth season (Park et al. 2013); hourly to daily variability was best related to changes in the trajectory, altitude, and speed of air masses passing over the DMS sources, while weekly variability was correlated to that of chlorophyll-a (CHL) in surrounding ocean waters and the changes in SIE. Atmospheric DMS concentrations decrease several orders of magnitude outside the summer season (Mungall et al. 2016; Park et al. 2013).

Observations in the high Arctic, although limited (Leck et al. 2001, 2004, 1996; Tjernström et al. 2004), show highest MBAs in summer clean-air conditions and particle number increasing from June through August; similar observations are recorded for the Canadian Arctic (Leaitch et al. 2013). Air masses arriving in the Arctic during summer originate from sectors over the oceans with limited man-made activities (Leck and Svensson 2015), and the transport into the Arctic is slower compared to winter conditions (Stohl 2006). Summer conditions are thus much more pristine, and the aerosol shifts to smaller particle sizes (Heintzenberg et al. 2015, 2006) with higher organic content (e.g., Hamacher-Barth et al. 2016). Summer pan-Arctic crossings have shown aerosol methanesulfonic acid (MSA; an atmospheric photodegradation product of DMS) concentrations during the phytoplankton growth period to be highest in the Norwegian Sea and lowest over the central 
Arctic pack ice during the same time (Ye et al. 2015), supporting the link between DMS emissions and ice-cover control of air-sea exchange. Decadal time series collected at coastal sites show MSA decline in the 1980s and 1990s in summer, followed by a steady increase since 2000 as a function of decreased SIE and the northward migration of the ice edge, where high aqueous DMS concentrations have been reported (Sharma et al. 2012). A summertime increase in MSA has also been reported for Barrow, Alaska (now known as Utqiagivik), by Quinn et al. (2009). Although most model projections do not account for the loss of sea ice extent as a habitat for ice algae, which are known to be strong DMS producers (Levasseur 2013), recent observations suggest thinner, more ponded, and transparent sea ice may result in high DMS fluxes from large under-ice blooms instead (Galindo et al. 2014).

Field measurements in the Antarctic sea ice zone. Similar to the Arctic, data in Antarctic sea ice reveal very high but variable concentrations of the MBA precursors, DMSP and DMS (Curran et al. 1998; Delille et al. 2007; Kirst et al. 1991; Nomura et al. 2011; Trevena et al. 2003; Zemmelink et al. 2005). Average DMSP concentrations from pack ice are $\sim 168 \mathrm{nM}$ and reflect the spring-summer and winter-spring transition periods. DMSP concentrations in sea ice from the Dumont D'Urville region in winter averaged $40 \mathrm{nM}$ (Curran et al. 1998), reflecting the lower amounts of algal biomass in winter sea ice. DMS in pack and fast ice collected in spring from the Indian Ocean sector of the SO averaged $12 \mathrm{nM}$ (range: $<0.3-75 \mathrm{nM}$; Trevena and Jones 2006), with mean values of $12 \mathrm{nM}$ (range: $<0.3-369 \mathrm{nM}$ ) in fast ice collected in spring-summer from McMurdo Sound (Carnat et al. 2014).

Trevena and Jones (2006) reported concentrations of DMS and DMSP from 62 sea ice cores of pack and fast ice at 27 sites in the East Antarctic SIZ $\left(64^{\circ}-110^{\circ} \mathrm{E}\right)$ from the coastline north to $62^{\circ} \mathrm{S}$. Concentrations of DMS in 81 sections of sea ice ranged from $<0.3$ to $75 \mathrm{nM}$, with an average of $12 \mathrm{nM}$; DMSP in 60 whole sea ice cores ranged from 25 to $796 \mathrm{nM}$ and showed a negative relationship with increasing ice thickness. Extremely high DMSP concentrations were found in two cores of rafted sea ice (2,910 and 1,110 nM). The relationship of DMSP with ice thickness (excluding rafted ice) suggests that a release of large amounts of DMSP during sea ice melting may occur in discrete areas defined by ice thickness distribution and may produce "hot spots" of elevated seawater DMS concentration on the order of $100 \mathrm{nM}$.

Although several aerosol studies have been conducted on the Antarctic continent (Becagli et al. 2009;
Legrand et al. 2001), measurements in the SO SIZ are quite limited (Bates et al. 1998). Among the few studies are those in the austral summer of 2009/10 by Koga et al. (2014) and by Humphries et al. (2016) during the austral spring of 2012, being the first in the East Antarctic pack ice. In the latter study, the ship traversed between eight ice floes that were used as temporary research stations. Boundary layer CCN concentrations exhibited a fivefold increase moving across the polar front, with mean polar cell (between $60^{\circ}$ and $70^{\circ} \mathrm{S}$ ) concentrations of $1,130 \mathrm{~cm}^{-3}$-higher than any observed elsewhere in the Antarctic region (Humphries et al. 2016).

Satellite data on AOD, CHL, and sea ice. To maximize the time series length, satellite data on CHL concentration and AOD were obtained from both the Sea-Viewing Wide Field-of-View Sensor (SeaWiFs; available from September 1997 to December 2010) and the Moderate Resolution Imaging Spectroradiometer (MODIS) Aqua archives (reprocessing version 2013.1) for January 2011-December 2015. Compared with groundbased Aerosol Robotic Network (AERONET) observations of AOD, satellite-derived aerosol products estimate AOD to within the expected accuracy more than $60 \%$ of the time over ocean (Remer et al. 2008). We utilize level-3 (4-km equirectangular projection) 8-day mapped CHL data and level-3 AOD at $865 \mathrm{~nm}$ at 9-km spatial resolution (http://oceancolor.gsfc .nasa.gov/cgi//3). Daily SIE (fractional) was obtained at $25 \mathrm{~km} \times 25 \mathrm{~km}$ spatial resolution from the National Oceanic and Atmospheric Administration/National Snow and Ice Data Center (NOAA/NSIDC) climate data record of passive microwave sea ice concentration archive (https://nsidc.org/data/seaice_index/archives .html).

Because of high sea ice coverage and high zenith angle of the sun at high latitudes, CHL and AOD data are only available from $85^{\circ} \mathrm{N}$ southward in the Northern Hemisphere and for part of the year (March-September). Both CHL and AOD retrievals are subject to possible pixel contamination by cloud in the SO (Toth et al. 2013) and sea ice north of $80^{\circ} \mathrm{N}$ (Belanger et al. 2007). To minimize this error, our data analysis in the Arctic Ocean was restricted to the south of $80^{\circ} \mathrm{N}$. Cloud cover is high in the Arctic, and consequently, satellite retrievals in the study region were usually limited to between $10 \%$ and $15 \%$ of the total available pixels. We note that this leads to the possibility of negative bias in estimation of spatially averaged CHL and AOD values. However, our primary goal here is not the accurate estimation of $\mathrm{CHL}$ or AOD levels but rather to examine 
October Antarctic SIE Anomaly

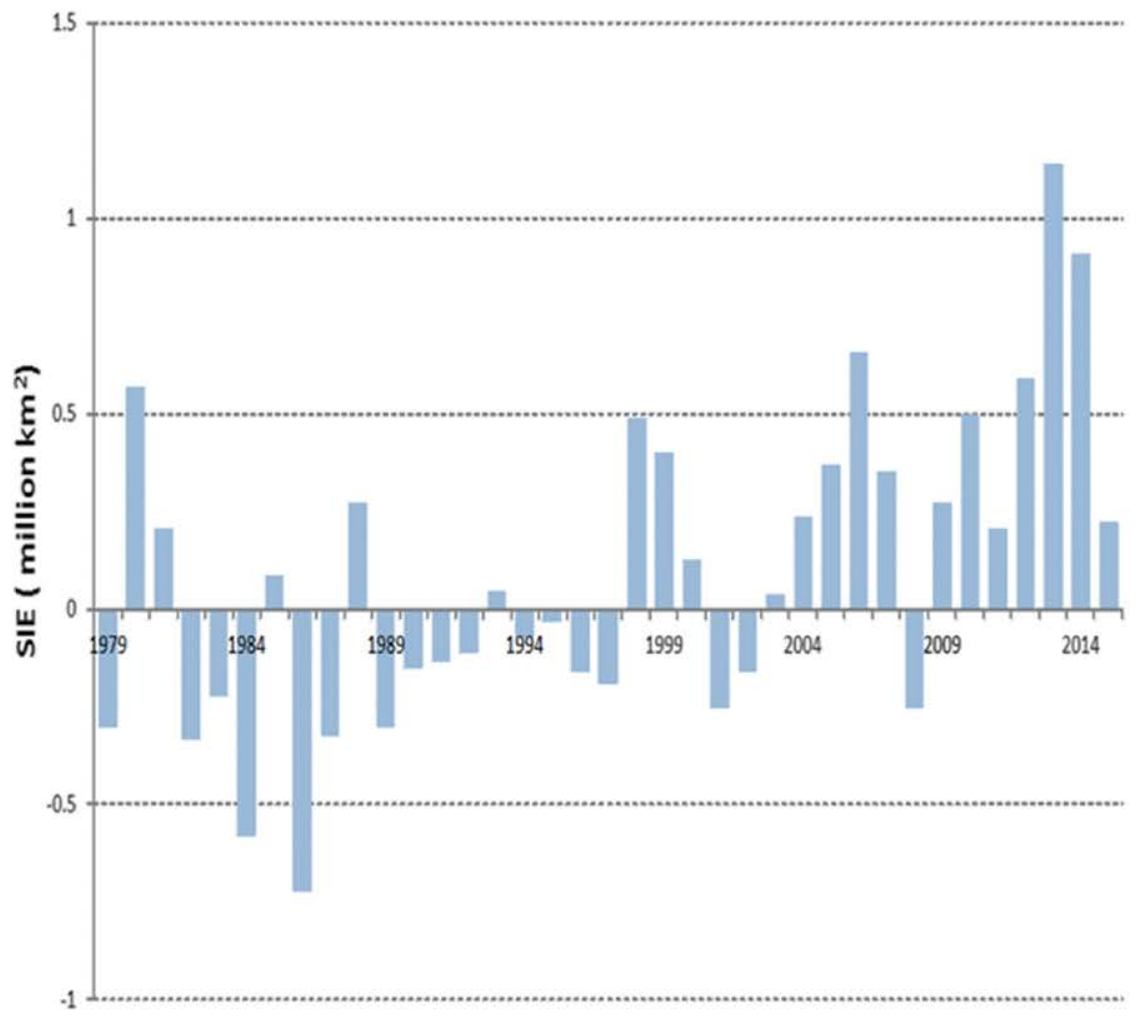

February Arctic SIE Anomaly

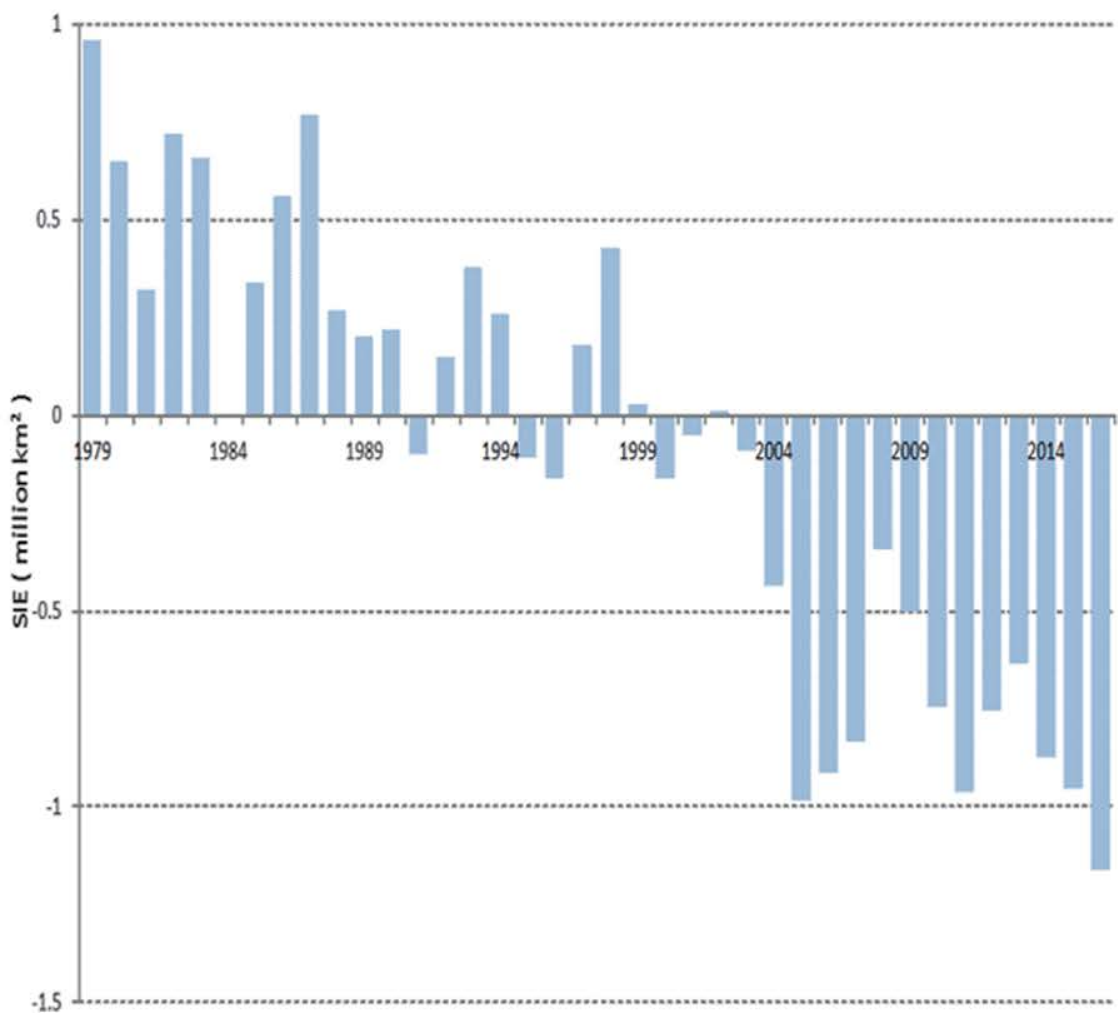

FIG. 4. Late winter SIE anomalies (relative to the 198I-2010 mean) for (a) Antarctic and (b) Arctic. the synchronicity of their annual cycles with respect to sea ice dynamics.

SEA ICE. The mean annual cycles in Arctic and Antarctic SIE are shown in Figs. $3 \mathrm{a}$ and $3 \mathrm{~b}$, respectively. In the Arctic, sea ice melt commences during March, continuing through spring and summer, with SIE reaching a minimum in September. During this 6-month period, SIE is reduced by approximately $9 \times 10^{6} \mathrm{~km}^{2}$. In one of the few Arctic studies that examine the relationship between aerosols, CHL, and sea ice, Gabric et al. (2014) found considerable interannual variability in both the onset of melt and the extent of sea ice loss during summer.

By contrast, the melt cycle in the Antarctic is more rapid, commencing in October and reaching a minimum extent the following February. The reduction in SIE is also more extensive in the Antarctic, with $11 \times 10^{6} \mathrm{~km}^{2}$ lost just between October and December and a total of $15 \times 10^{6} \mathrm{~km}^{2}$ by late summer, on average.

Maximum winter SIE anomalies are shown for the $\mathrm{SH}$ and $\mathrm{NH}$ in Figs. 4a and $4 \mathrm{~b}$, respectively. There is considerable interannual variability in SIE in both hemispheres, although fluctuations are perhaps more marked in the Antarctic. The change in the Arctic from positive to negative SIE anomalies is particularly evident from the start of the twenty-first 
century, and the negative trend is significant for the entire time period (slope: -0.05 ; coefficient of determination $R^{2}=0.81$ ). This trend contrasts with that for the Antarctic, where mostly positive SIE anomalies have been recorded since the turn of the century.

CHL AND AOD. ARCTIC. Analysis of CHL and AOD 8 -day data in the whole Arctic Ocean $\left(66^{\circ}-80^{\circ} \mathrm{N}\right)$ shows strong seasonality in both time series, with a peak in AOD during spring (April) preceding the vernal CHL maximum (usually in May), followed by an often higher CHL peak during late summer. AOD decreases during summer before increasing again around or after the second CHL peak. This pattern is evident in most years and is illustrated for years 2008 and 2011 in Fig. 5. The early spring peak in AOD is most likely influenced by Arctic haze, which tends to reach a maximum in MarchApril, thereafter declining through summer (Quinn et al. 2007). Ground-based measurements of AOD at Ny-Ålesund, Spitzbergen (Norway, $78.95^{\circ} \mathrm{N}$ ), report lower values of AOD in summer ( 0.05; Herber et al. 2002), similar to the satellite values reported here. During summer, the high Arctic is isolated from midlatitude aerosol sources because the polar front is usually located around $70^{\circ} \mathrm{N}$ (Herber et al. 2002). The increase in AOD during late summer shown in Fig. 5 is likely associated with postbloom emissions of MBA (Leck and Persson 1996; Leck et al. 1996).

To illustrate the impact of sea ice in regional Arctic seas, we examine two contrasting regions (in terms of SIE) - the Kara and Barents Seas. The CHL and AOD

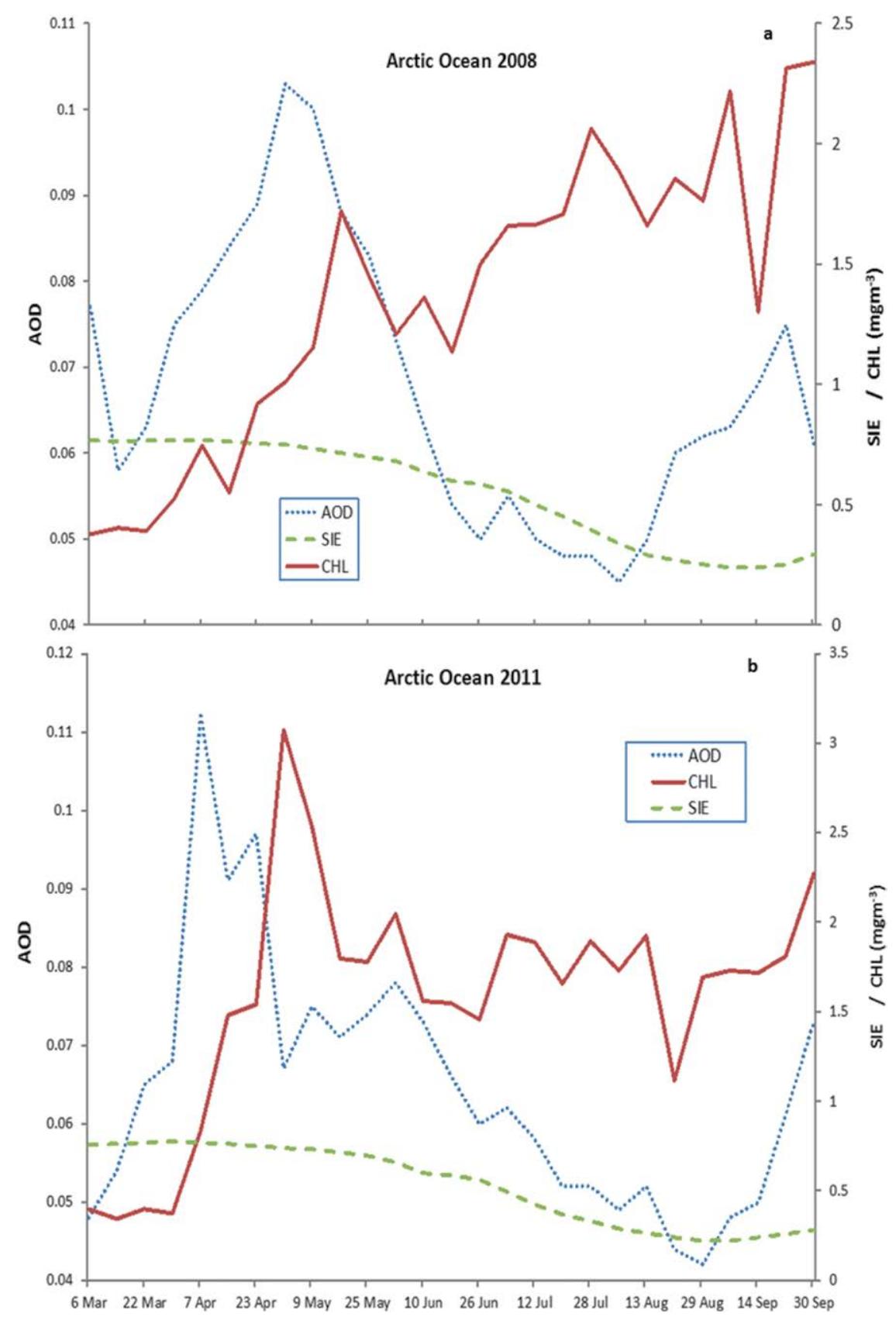

FIG. 5. CHL, AOD, and SIE (fraction) for the whole Arctic Ocean $\left(66^{\circ}-90^{\circ} \mathrm{N}\right)$ in (a) 2008 and (b) $201 \mathrm{I}$.

time series for the Kara Sea $\left(68^{\circ}-81^{\circ} \mathrm{N}, 56^{\circ}-100^{\circ} \mathrm{E}\right)$ and the adjacent but relatively less ice-covered Barents Sea $\left(68^{\circ}-81^{\circ} \mathrm{N}, 17^{\circ}-56^{\circ} \mathrm{E}\right)$ are shown in Fig. 6 . In the Kara Sea, AOD consistently peaks from mid-April to early May, preceding the peak in CHL by up to two months.

By contrast, in the Barents Sea, the AOD and CHL peaks are much closer, and in some years almost coincident (Figs. $7 \mathrm{~b}$ and $7 \mathrm{c}$ ). The sea ice in the Barents Sea in 2007 is mostly confined to north of $76^{\circ} \mathrm{N}$ (Fig. 7a), resulting in a larger and longer-lived 


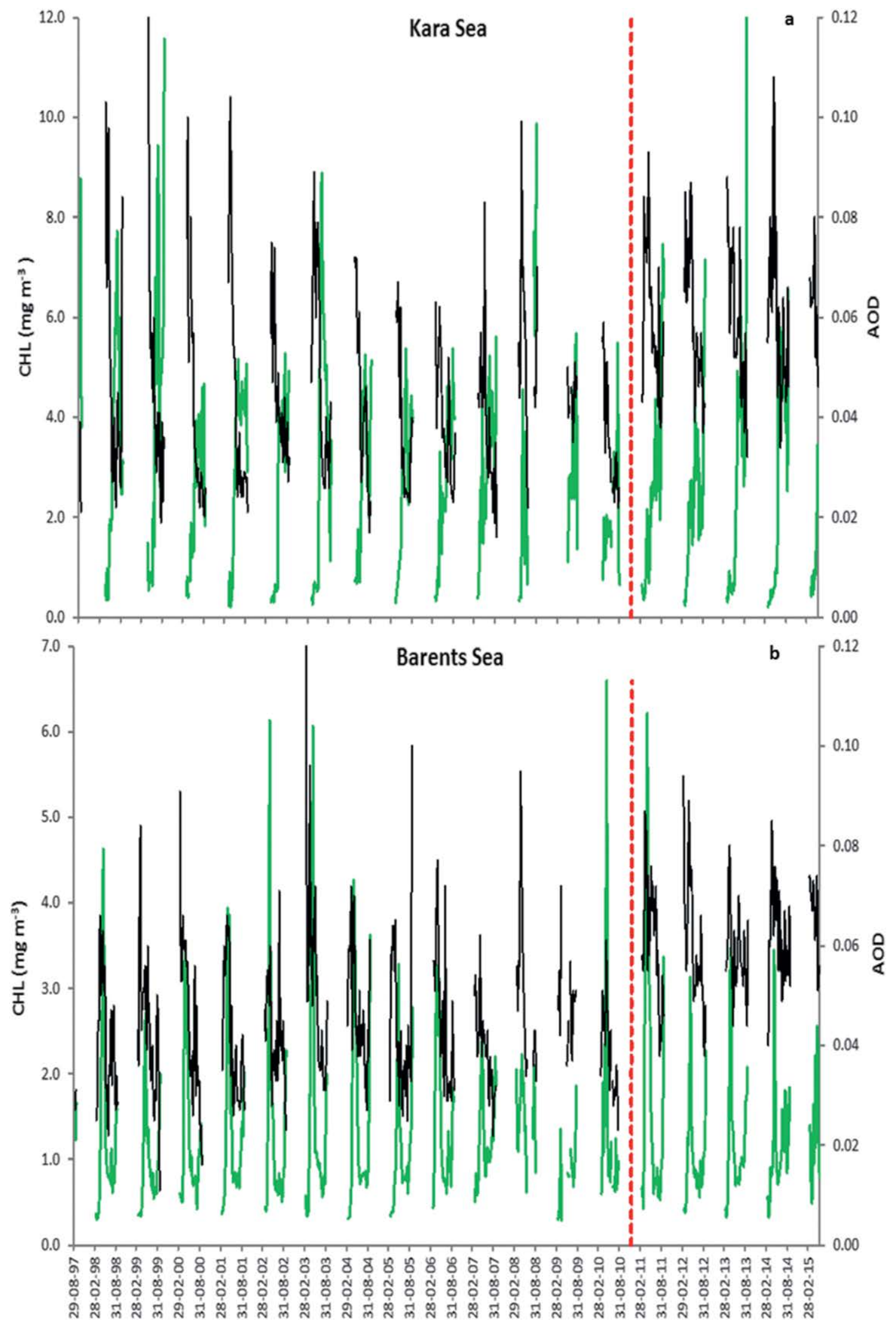

$-\mathrm{CHL} \quad \cdots$ Switch to Modis data -AOD

FIG. 6. Time series (1997-2015) of 8-day satellite-derived CHL and AOD in (a) Kara Sea $\left(68^{\circ}-81^{\circ} \mathrm{N}, 56^{\circ}-100^{\circ} \mathrm{E}\right)$ and (b) Barents Sea $\left(68^{\circ}-81^{\circ} \mathrm{N}, 17^{\circ}-56^{\circ} \mathrm{E}\right)$. 
area of open water. Hovmöller plots of the CHL and AOD distribution (Figs. $7 \mathrm{~b}$ and $7 \mathrm{c}$, respectively) show CHL is high $\left(\approx 1 \mathrm{mg} \mathrm{m}^{-3}\right)$ in the southern ice-free half throughout the spring-summer seasons and displays little spatial relationship with AOD. MBA emissions in the Barents Sea are largely from open water. There is some correspondence between the zonal means in $\mathrm{CHL}$ and AOD between $72^{\circ}$ and $76^{\circ} \mathrm{N}$, with $\mathrm{CHL}$ slightly leading the peak in AOD and likely MBA emissions; however, atmospheric transport will smear any clear spatial correlation. This contrasts with the sea ice distribution in the Kara Sea in the same year, where the entire $68^{\circ}-80^{\circ} \mathrm{N}$ region has at least $50 \%$ ice cover until significant melting begins in June (Fig. 8a). Here, the Hovmöller of CHL (Fig. 8b) shows the increase in pelagic phytoplankton is delayed until late June-July; however, AOD increases during May-June (Fig. 8c), suggesting a source of aerosol during the ice melt period (most likely from underice or ice algae). These asynchronous patterns are repeated throughout the years (2003-15) analyzed. Similar patterns for outof-phase CHL and AOD annual cycles are observed in the Pacific-influenced Chukchi Sea (not shown), which has ice cover of intermediate extent between the Kara and Barents Seas. Few field atmospheric data exist to confirm these patterns.
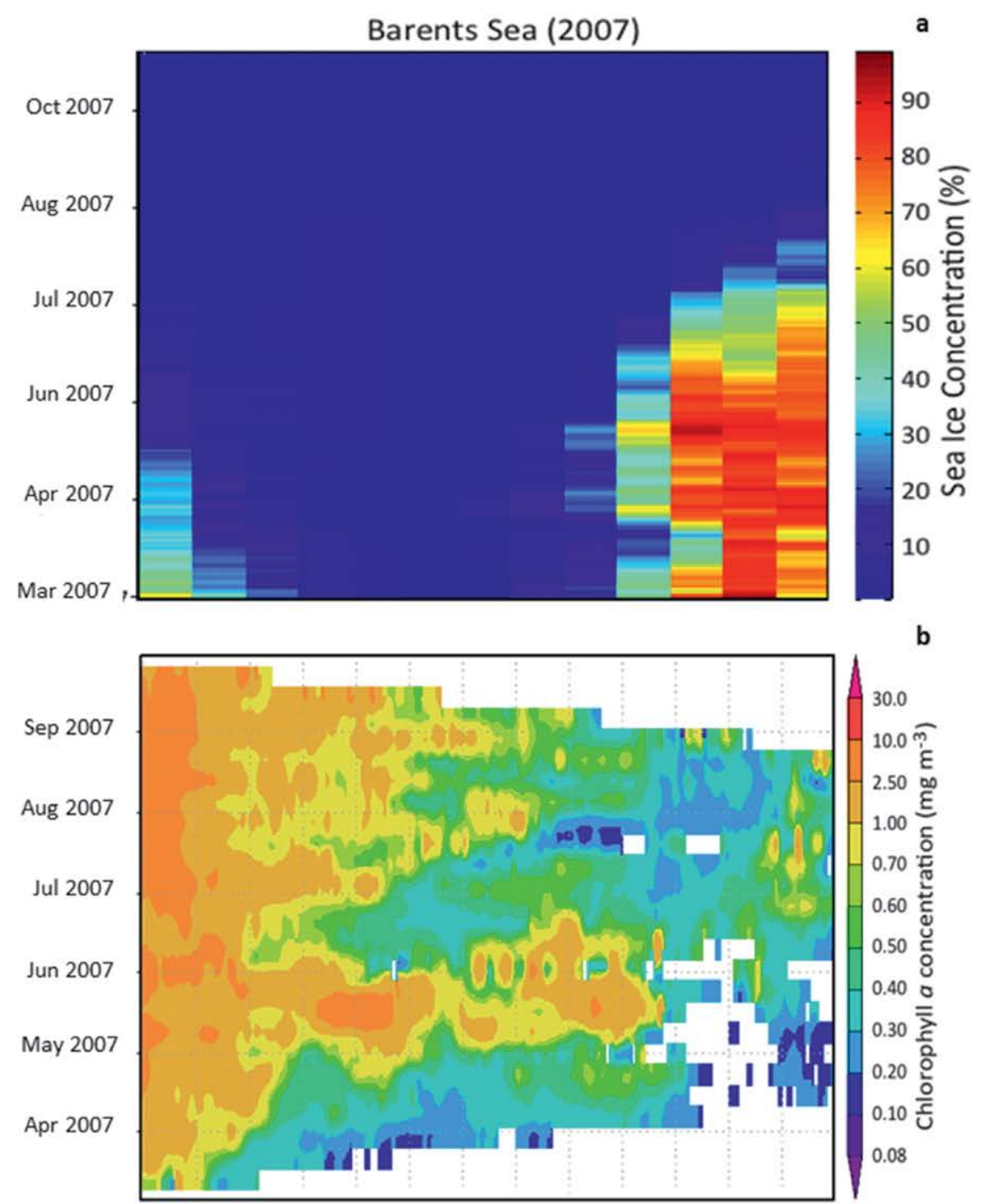

C

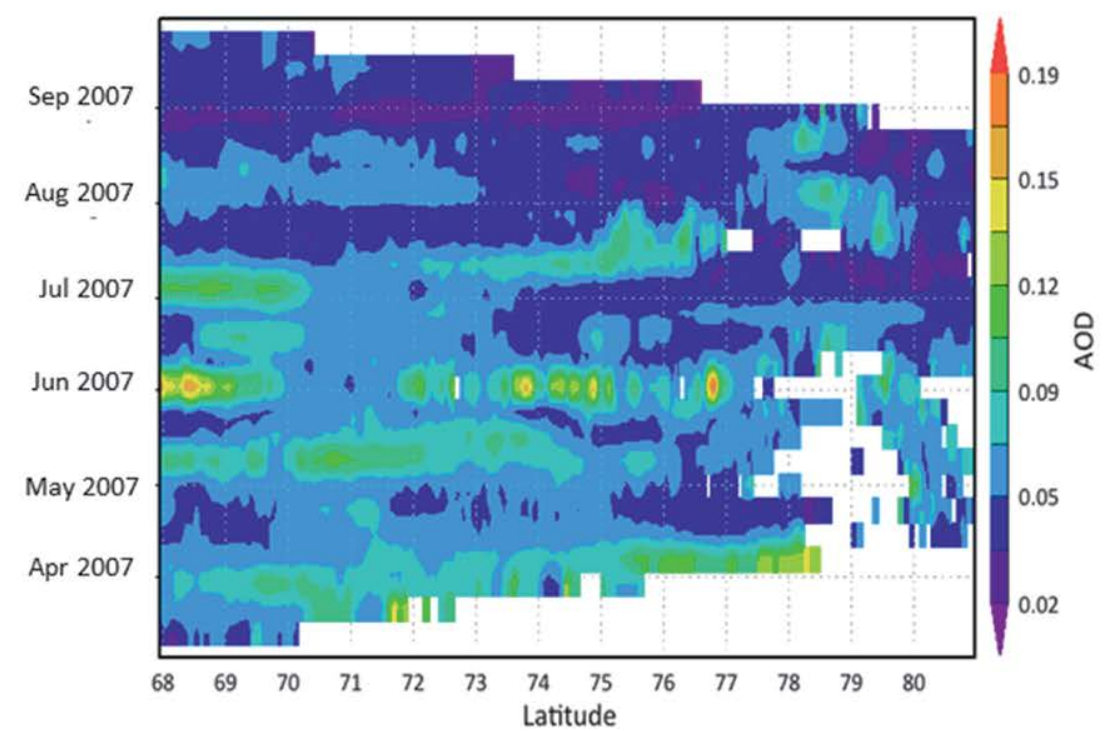

Fig. 7. Hovmöller plots of (a) SIE, (b) CHL, and (c) AOD for the Barents Sea during spring-summer of 2007. 


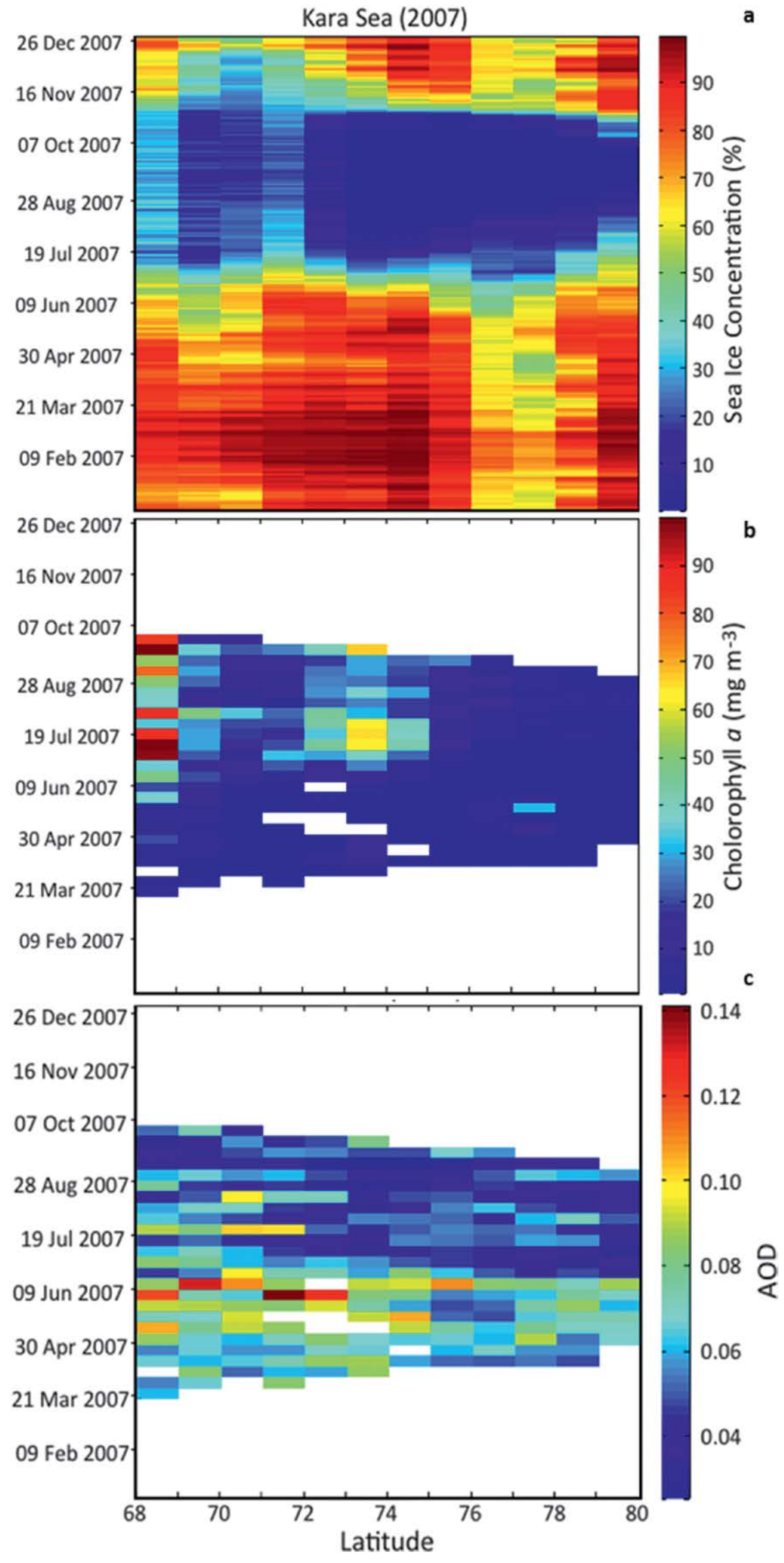

Fig. 8. As in Fig. 7, but for the Kara Sea.
ANTARCTIC. Figure 9 shows the zonal-mean time series of $\mathrm{AOD}$ and $\mathrm{CHL}$ in $55^{\circ}-60^{\circ}$, $60^{\circ}-65^{\circ}$, and $65^{\circ}-70^{\circ} \mathrm{S}$ latitude bands corresponding to open water, MIZ, and SIZ, respectively. In the SIZ, the peak in AOD occurs from late September to mid-October. There is a clear difference between the coherence in the AOD and CHL cycles in the most northern and the two southern bands, with a distinct lag between peaks in AOD and CHL in the SIZ.

Previously, Gabric et al. (2005) found a clear latitudinal difference in the cross correlation between time series of satellite-derived $\mathrm{CHL}$ and AOD in the East Antarctic SIZ, with the AOD peak preceding the CHL bloom by up to 6 weeks. This suggests that substantial trace gas emissions (aerosol precursors) or primary MBAs are being emitted over the SIZ in the austral spring (OctoberDecember) as sea ice melts. This is supported by field data, as discussed above, that record extremely high levels of sulfur species in sea ice, surface seawater, and the overlying atmosphere during ice melt or during disruption of the ice pack by ship crossings (Humphries et al. 2016; Jones et al. 2010; Koga et al. 2014).

Recent estimates of DMS flux in East Antarctica during the ice melt period and the ice-free summer are presented in Table 1 (Trevena and Jones 2012). The average DMS flux from surface pack ice at Davis Station during November was estimated to be $54 \mu \mathrm{mol} \mathrm{m}^{-2}$ day $^{-1}$ (Table 1), comparable to the 


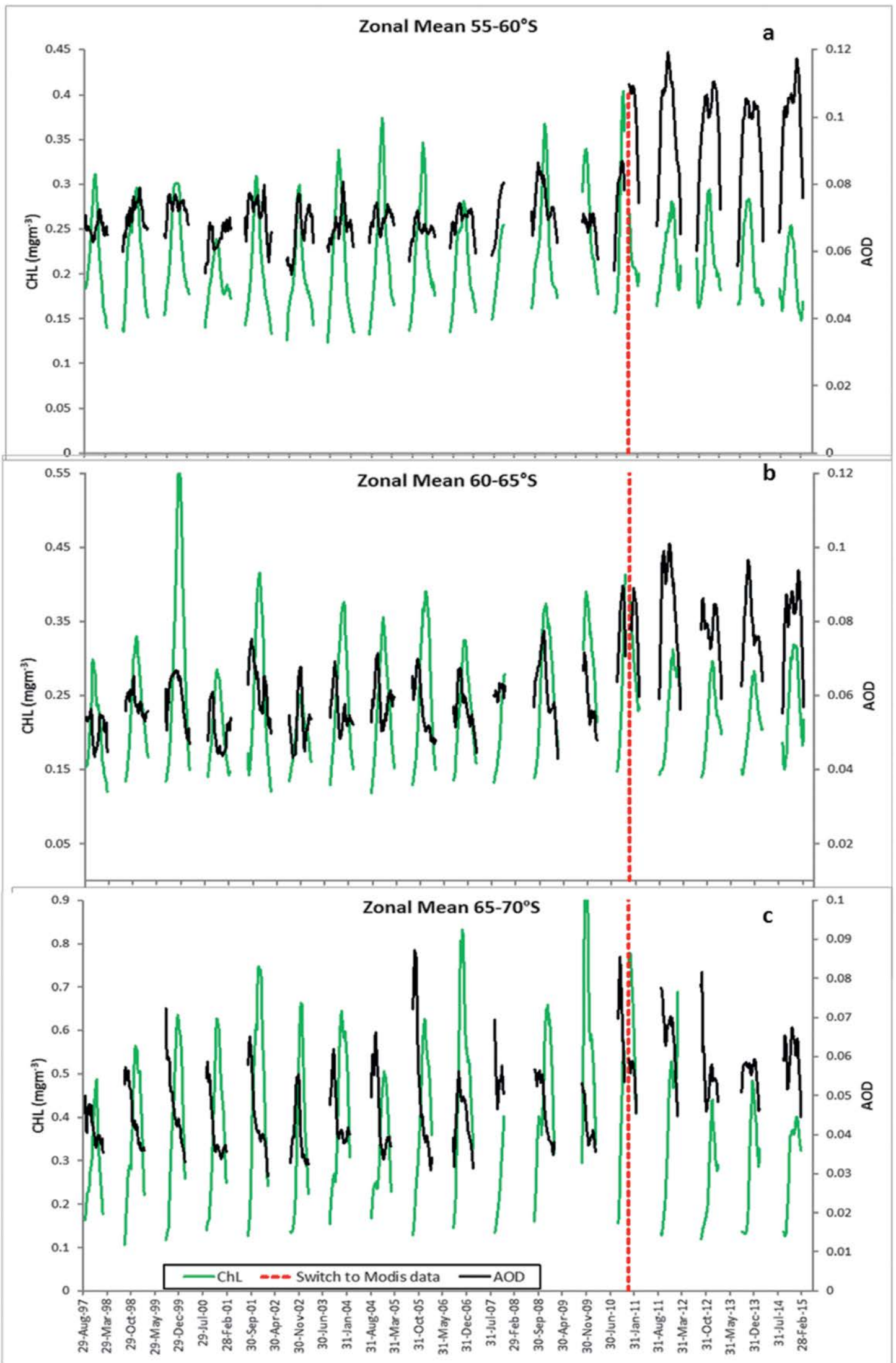

Fig. 9. Time series of Antarctic zonal-average 8-day satellite-derived CHL and AOD in $5^{\circ}$ latitude bands: (a) $55^{\circ}-60^{\circ}$, (b) $60^{\circ}-65^{\circ}$, and (c) $65^{\circ}-70^{\circ} \mathrm{S}$. 
TABLE I. DMS concentration and flux estimates (mean, with range in parentheses) for a variety of sea ice and seawater sources during the period of ice melting and the ice-free summer in East Antarctic.

\begin{tabular}{|c|c|c|c|}
\hline Source & Time period & DMS (nM) & Flux $\left(\mu \mathrm{mol} \mathrm{m}^{-2} \mathrm{day}^{-1}\right)$ \\
\hline Surface pack ice & Nov & $3 I^{a}$ & $54(I-325)$ \\
\hline Surface fast ice & Nov & $16^{a}$ & $28(0-168)$ \\
\hline Surface fast ice melt pool & mid-Dec & 1 & $(0.5-7)$ \\
\hline Fast ice tide crack & late Dec & 12 & $(6-8 I)$ \\
\hline Davis Station area seawater & 2 days following fast ice breakout & 12 & $(45-84)$ \\
\hline Davis Station area seawater & Jan-Feb & 3 & $27(I-10 I)$ \\
\hline \multirow{2}{*}{ Retreating pack ice seawater ${ }^{b}$} & 2 day transect mid-Dec & $31(21-37)$ & $12^{c}(1.2-26)$ \\
\hline & Dec & 31 & $23^{d}$ \\
\hline
\end{tabular}

${ }^{\text {a }}$ Based on average DMS:DMSP ratio of 0.1 and average surface assemblage concentration (Trevena and Jones 2012 ).

b Flux includes influence of variable ice cover.

c Mean of individual flux estimates for each of the five sample sites.

d Single calculation based on average transect DMS concentration and monthly wind speed of $10 \mathrm{~m} \mathrm{~s}^{-1}$ (Trevena and Jones 2012 ).

upper estimates in late November and December reported by Zemmelink et al. (2008) and much higher than those reported by Tison et al. (2010) during December 2004, both in the Weddell Sea. However, the daily flux estimate ranged from 1 to $325 \mu \mathrm{mol} \mathrm{m}^{-2}$ day $^{-1}$, primarily because of variation in wind speed. The average DMS flux estimate from fast ice was 30\% lower than from pack ice because of the lower DMS concentration in surface fast ice (Table 1) and was similar to that in open water later in the season, perhaps as a result of prolonged ventilation and complex food-web processes (Trevena and Jones 2012).

A more detailed picture emerges in the plots of the space-time evolution of CHL, AOD, and SIE (Fig. 10) during the austral spring-summer of 2012/13 for the East Antarctic south of $60^{\circ} \mathrm{S}$. There is a distinct time lag between peaks in AOD (Fig. 10a) - which start in September-and the maximum in CHL during late November-December in the SIZ $\left(60^{\circ}-65^{\circ} \mathrm{S}\right.$; Fig. 10b). Sea ice melt occurs mainly at the lower latitudes $\left(60^{\circ}-65^{\circ} \mathrm{S}\right)$, commences in late September, and is followed by a brief refreeze in early October (Figs. 10c and 10d). There is a rapid increase in AOD during September, corresponding to the onset of ice melt, with a second AOD pulse in November as the melt gathers pace (Fig. 10d). This shows that AOD is affected by MBA emissions that occur during the sea ice melt period and preceding the main open water phytoplankton bloom period in December.

CONCLUSIONS. Our results indicate a clear connection between the annual cycle in sea ice and the atmospheric aerosol burden in polar seas. The data suggest a nexus between the maximum SIE, the subsequent melt period, and the atmospheric aerosol burden. Melting can trigger active microalgal exudation of MBA precursors such as DMS and DMSP by decreasing the salinity of the ice, as suggested by Delille et al. (2007). The sudden increase in light intensity when cells exit the ice pack may also trigger a rapid DMSP release (Galindo et al. 2016). This underscores the importance of the seasonal melt of sea ice in subsequent spring-summer MBA release. It is unknown whether a similar link exists at the time of freeze-up and sea ice formation in autumn that leads to brine extrusion [including dissolved organic matter (DOM)] to both water and air (Bowman and Deming 2010, 2016).

Levasseur (2013) has suggested that the production and emission of DMS will increase in the Arctic in future decades as seasonal sea ice cover recedes, because of an increase in open water and related effects of warming on the ocean mixed layer (Gabric et al. 2005). For example, warming will likely increase the sea ice melting rate and consequently shorten the melt season, with phytoplankton blooms occurring earlier in the spring. Overall, there will likely be increased annual PP in certain regions of the Arctic Ocean, mainly due to enhanced light availability (Arrigo et al. 2008b), but only when coupled with higher nutrient availability (Tremblay et al. 2015). Hence, the potential exists for enhanced MBA production and emission as a function of sea ice changes. Furthermore, the appearance of autumn phytoplankton blooms in Arctic shelf regions (Ardyna et al. 2014) - which did not occur on a regular basis-coupled with extensive first-year ice and frost flowers directly releasing MBAs (Bowman and Deming 2010) raises the possibility of autumnal fluxes, previously nonexistent. 

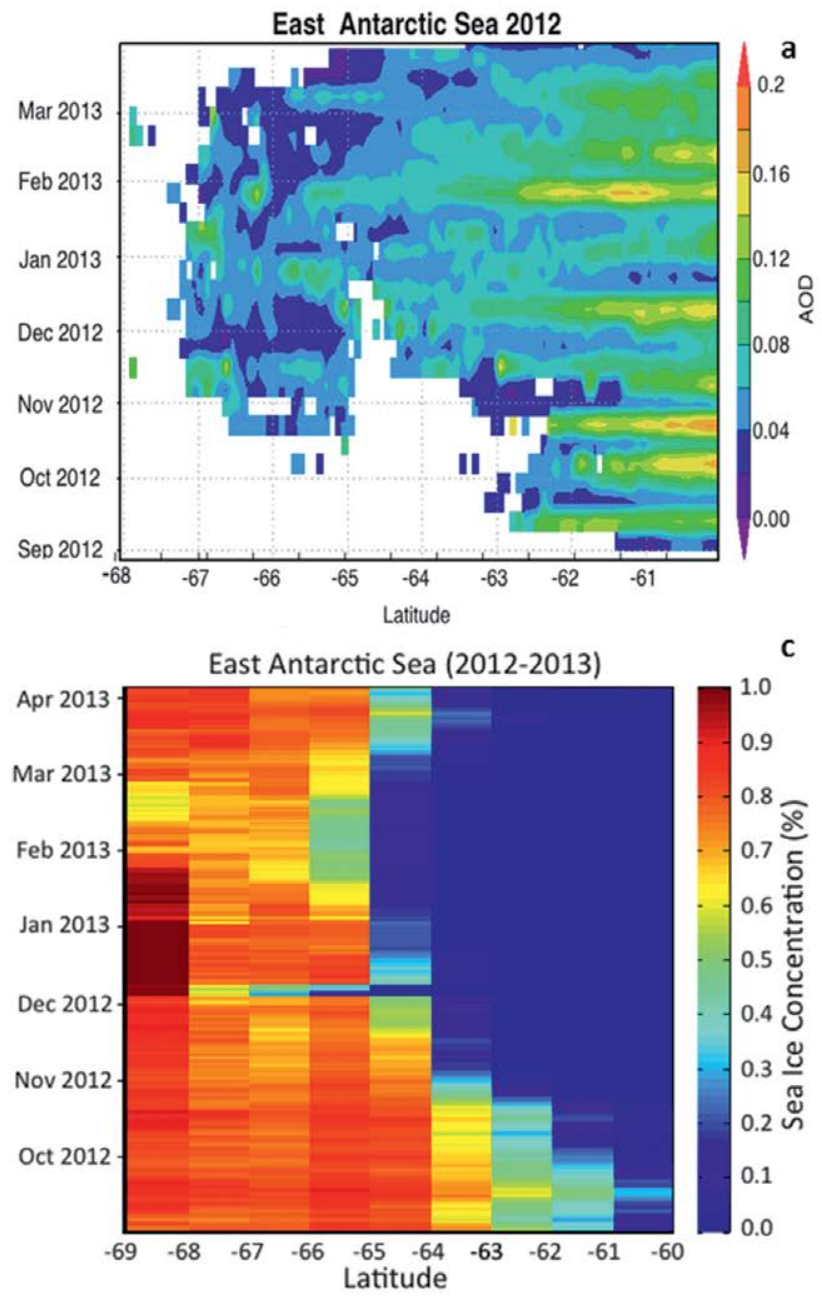
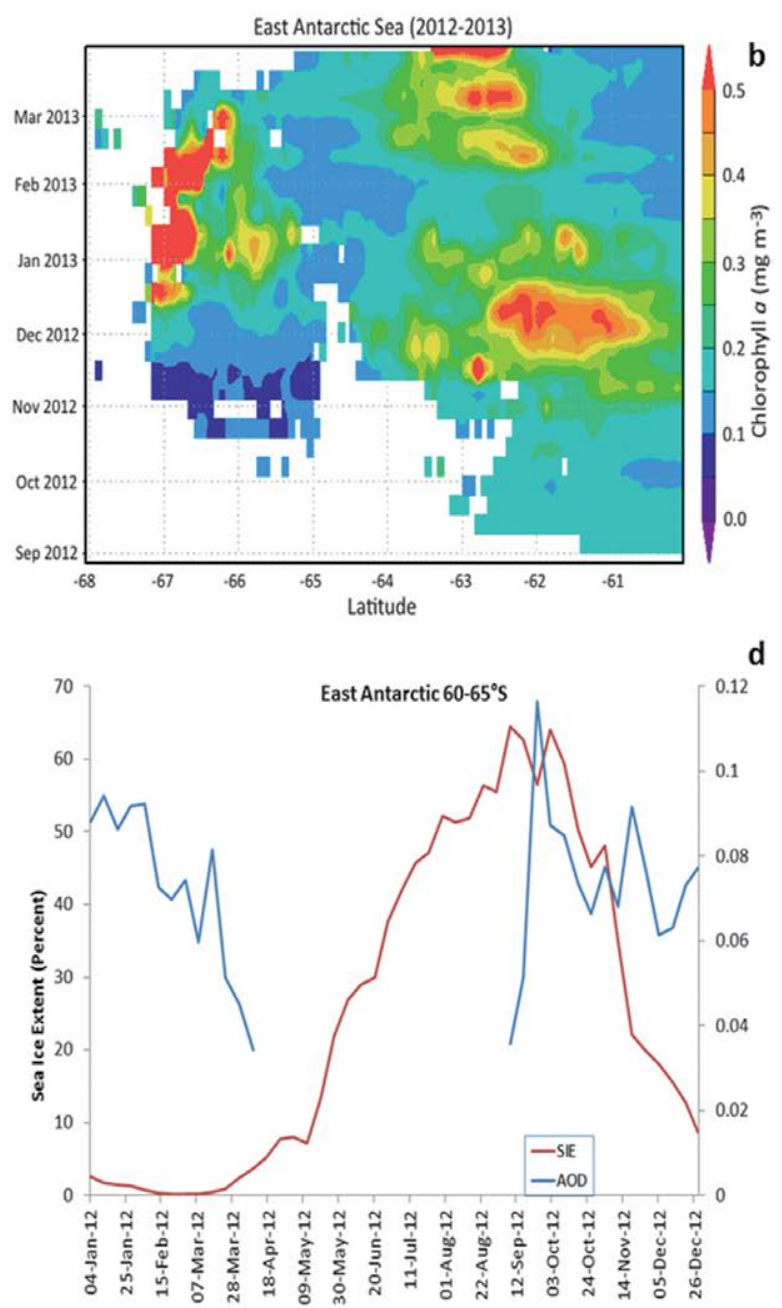

Fig. 10. Hovmöller plots of (a) AOD, (b) CHL, (c) SIE, and (d) time series of mean SIE and AOD in the East Antarctic $\left(60^{\circ}-65^{\circ} \mathrm{S}, 110^{\circ}-140^{\circ} \mathrm{E}\right)$ during 2012.

The impact of ocean acidification on polar MBA emissions is not yet well understood; although there is some evidence that ice algal communities will not be adversely affected by acidification (McMinn et al. 2014), the effect on pelagic algal communities is still unclear (Thoisen et al. 2015).

There is now strong evidence to suggest that ocean biology augments the aerosol and cloud droplet concentration and radiative forcing also over the biologically active $\mathrm{SO}$ by a significant amount (McCoy et al. 2015; Vallina et al. 2006). However, the relationship of aerosol emissions with SO sea ice variability is more complex, with the cause of the overall increase in Antarctic SIE still greatly debated. If the positive trend in Antarctic SIE were to continue, and if this were accompanied by an accelerated ice melt season (due to warming), the conditions may lead to increased and intensified vernal phytoplankton bloom and MBA emissions. Field studies suggest that rapid sea ice breakout in coastal regions of Antarctica can result in fast DMSP production events during spring (Vance et al. 2013). However, how the intensity of such enhanced blooms might affect total seasonal PP and MBA emissions in the SO requires further investigation (Cameron-Smith et al. 2011). It is clear that climate models will need to incorporate the dynamic response of ocean biology to warming and changes in sea ice to accurately model future changes in MBA emissions.

ACKNOWLEDGMENTS. We gratefully acknowledge the NASA Ocean Biology Processing Group for providing SeaWiFs and MODIS Aqua level-3 data on chlorophyll-a and AOD. The sea ice data were provided by the National Snow and Ice Data Center, University of Colorado, Boulder. Matrai and Middleton were supported by the National Science Foundation (PLR-1417517). Jones was partially funded by a grant from the Australian Research Council (DP150101649). 
REFERENCES

Ardyna, M., M. Babin, M. Gosselin, E. Devred, L. Rainville, and J. É. Tremblay, 2014: Recent Arctic Ocean sea ice loss triggers novel fall phytoplankton blooms. Geophys. Res. Lett., 41, 6207-6212, https:// doi.org/10.1002/2014GL061047.

Arndt, D. S., J. Blunden, and K. W. Willett, 2015: Introduction [in "State of the Climate in 2014"]. Bull. Amer. Meteor. Soc., 96 (7), S1, https://doi.org/10.117 5/2015BAMSStateoftheClimate.1.

Arrigo, K. R., 2014: Sea ice ecosystems. Annu. Rev. Mar. Sci., 6, 439-467, https://doi.org/10.1146/annurev-marine $-010213-135103$.

_- and G. L. van Dijken, 2015: Continued increases in Arctic Ocean primary production. Prog. Oceanogr., 136, 60-70, https://doi.org/10.1016/j.pocean.2015.05.002.

,-- , and S. Bushinsky, 2008a: Primary production in the Southern Ocean, 1997-2006. J. Geophys. Res., 113, C08004, https://doi.org/10.1029/2007JC004551.

—,$\ldots$, and S. Pabi, 2008b: Impact of a shrinking Arctic ice cover on marine primary production. Geophys. Res. Lett., 35, L19603, https://doi.org/10.1029 /2008GL035028.

— , and Coauthors, 2012: Massive phytoplankton blooms under Arctic sea ice. Science, 336, 1408-1408, https://doi.org/10.1126/science.1215065.

Ayers, G. P., and J. M. Cainey, 2007: The CLAW hypothesis: A review of the major developments. Environ. Chem., 4, 366-374, https://doi.org/10.1071/EN07080.

Babin, M., K. Arrigo, S. Bélanger, and M.-H. Forget, Eds., 2015: Ocean colour remote sensing in polar seas. International Ocean Colour Coordinating Group Rep. 16, 135 pp., www.ioccg.org/reports/IOCCG _Report_16_2015.pdf.

Bates, T. S., B. J. Huebert, J. L. Gras, F. B. Griffiths, and P. A. Durkee, 1998: International Global Atmospheric Chemistry (IGAC) Project's first Aerosol Characterization Experiment (ACE-1): Overview. J. Geophys. Res., 103, 16297-16318, https://doi.org /10.1029/97JD03741.

Becagli, S., and Coauthors, 2009: Methanesulphonic acid (MSA) stratigraphy from a Talos Dome ice core as a tool in depicting sea ice changes and southern atmospheric circulation over the previous 140 years. Atmos. Environ., 43, 1051-1058, https://doi.org/10.1016/j .atmosenv.2008.11.015.

— , and Coauthors, 2016: Relationships linking primary production, sea ice melting, and biogenic aerosol in the Arctic. Atmos. Environ., 136, 1-15, https://doi .org/10.1016/j.atmosenv.2016.04.002.

Belanger, S., J. K. Ehn, and M. Babin, 2007: Impact of sea ice on the retrieval of water-leaving reflectance, chlorophyll $a$ concentration and inherent optical properties from satellite ocean color data. Remote Sens. Environ., 111, 51-68, https://doi.org/10.1016/j .rse.2007.03.013.

Bintanja, R., G. J. van Oldenborgh, S. S. Drijfhout, B. Wouters, and C. A. Katsman, 2013: Important role for ocean warming and increased ice-shelf melt in Antarctic sea-ice expansion. Nat. Geosci., 6, 376-379, https://doi.org/10.1038/ngeo1767.

- - _ , and C. A. Katsman, 2015: The effect of increased fresh water from Antarctic ice shelves on future trends in Antarctic sea ice. Ann. Glaciol., 56, 120-126, https://doi.org/10.3189/2015AoG69A001.

Bowman, J., and J. Deming, 2010: Elevated bacterial abundance and exopolymers in saline frost flowers and implications for atmospheric chemistry and microbial dispersal. Geophys. Res. Lett., 37, L13501, https://doi.org/10.1029/2010GL043020.

- , and — 2016: Wind-driven distribution of bacteria in coastal Antarctica: Evidence from the Ross Sea region. Polar Biol., 40, 25-35, https://doi.org/10.1007 /s00300-016-1921-2.

Bromwich, D. H., J. P. Nicolas, A. J. Monaghan, M. A. Lazzara, L. M. Keller, G. A. Weidner, and A. B. Wilson, 2013: Central West Antarctica among the most rapidly warming regions on Earth. Nat. Geosci., 6, 139-145, https://doi.org/10.1038/ngeo1671.

Browse, J., K. S. Carslaw, G. W. Mann, C. E. Birch, S. R. Arnold, and C. Leck, 2014: The complex response of Arctic aerosol to sea-ice retreat. Atmos. Chem. Phys., 14, 7543-7557, https://doi.org/10.5194/acp-14-7543-2014.

Cameron-Smith, P., S. Elliott, M. Maltrud, D. Erickson, and O. Wingenter, 2011: Changes in dimethyl sulfide oceanic distribution due to climate change. Geophys. Res. Lett., 38, L07704, https://doi.org/10.1029 /2011GL047069.

Carnat, G., and Coauthors, 2014: Physical and biological controls on DMS, P dynamics in ice shelf-influenced fast ice during a winter-spring and a spring-summer transitions. J. Geophys. Res. Oceans, 119, 2882-2905, https://doi.org/10.1002/2013JC009381.

Carpenter, L. J., P. S. Liss, and S. A. Penkett, 2003: Marine organohalogens in the atmosphere over the Atlantic and Southern Oceans. J. Geophys. Res., 108, 4256, https://doi.org/10.1029/2002JD002769.

Carslaw, K. S., O. Boucher, D. V. Spracklen, G. W. Mann, J. G. L. Rae, S. Woodward, and M. Kulmala, 2010: A review of natural aerosol interactions and feedbacks within the Earth system. Atmos. Chem. Phys., 10, 1701-1737, https://doi.org/10.5194/acp-10-1701-2010. —-, and Coauthors, 2013: Large contribution of natural aerosols to uncertainty in indirect forcing. Nature, 503, 67-71, https://doi.org/10.1038/nature12674. 
Carton, J. A., Y. Ding, and K. R. Arrigo, 2015: The seasonal cycle of the Arctic Ocean under climate change. Geophys. Res. Lett., 42, 7681-7686, https:// doi.org/10.1002/2015GL064514.

Chang, R. Y.-W., and Coauthors, 2011: Relating atmospheric and oceanic DMS levels to particle nucleation events in the Canadian Arctic. J. Geophys. Res., 116, D00S03, https://doi.org/10.1029/2011JD015926.

Chen, L. Q., J. J. Wang, Y. Gao, G. J. Xu, X. L. Yang, Q. Lin, and Y. H. Zhang, 2012: Latitudinal distributions of atmospheric MSA and MSA/nss- $\mathrm{SO}_{4}{ }^{2-}$ ratios in summer over the high latitude regions of the Southern and Northern Hemispheres. J. Geophys. Res., 117, D10306, https://doi.org/10.1029/2011JD016559.

Curran, M. A. J., G. B. Jones, and H. Burton, 1998: Spatial distribution of dimethylsulfide and dimethylsulfoniopropionate in the Australasian sector of the Southern Ocean. J. Geophys. Res., 103, 16677-16689, https://doi.org/10.1029/97JD03453.

Delille, B., B. Jourdain, A. V. Borges, J. L. Tison, and D. Delille, 2007: Biogas $\left(\mathrm{CO}_{2}, \mathrm{O}_{2}\right.$, dimethylsulfide) dynamics in spring Antarctic fast ice. Limnol. Oceanogr., 52, 1367-1379, https://doi.org/10.4319/lo .2007.52.4.1367.

Ducklow, H. W., and Coauthors, 2013: West Antarctic Peninsula: An ice-dependent coastal marine ecosystem in transition. Oceanography, 26, 190-203, https:// doi.org/10.5670/oceanog.2013.62.

Fan, T., C. Deser, and D. P. Schneider, 2014: Recent Antarctic sea ice trends in the context of Southern Ocean surface climate variations since 1950. Geophys. Res. Lett., 41, 2419-2426, https://doi.org/10.1002/2014GL059239.

Fedotov, V. I., N. V. Cherepanov, and K. P. Tyshko, 1998: Some features of the growth, structure and metamorphism of East Antarctic landfast sea ice. Antarctic Sea Ice: Physical Processes, Interactions, and Variability, M. O. Jeffries, Ed., Antarctic Research Series, Vol. 74, Amer. Geophys. Union, 343-354, https://doi.org /10.1029/AR074p0343.

Gabric, A. J., P. Matrai, and M. Vernet, 1999: Modelling the production of dimethylsulphide during the vernal bloom in the Barents Sea. Tellus, 51B, 919-938, https://doi.org/10.3402/tellusb.v51i5.16505.

—, B. Qu, P. Matrai, and A. C. Hirst, 2005: The simulated response of dimethylsulfide production in the Arctic Ocean to global warming. Tellus, 57B, 391-403, https://doi.org/10.3402/tellusb.v57i5.16564.

— - — - — C. Murphy, H. Lu, D. R. Lin, F. Qian, M. Zhao, 2014: Investigating the coupling between phytoplankton biomass, aerosol optical depth and seaice cover in the Greenland Sea. Dyn. Atmos. Oceans, 66, 94-109, https://doi.org/10.1016/j.dynatmoce .2014.03.001.
Gagné, M.-Ė., N. P. Gillett, and J. C. Fyfe, 2015: Observed and simulated changes in Antarctic sea ice extent over the past 50 years. Geophys. Res. Lett., 42, 90-95, https://doi.org/10.1002/2014gl062231.

Gali, M., and R. Simo, 2010: Occurrence and cycling of dimethylated sulfur compounds in the Arctic during summer receding of the ice edge. Mar. Chem., 122, 105-117, https://doi.org/10.1016/j.marchem 2010.07.003.

Galindo, V., and Coauthors, 2014: Biological and physical processes influencing sea ice, under-ice algae, and dimethylsulfoniopropionate during spring in the Canadian Arctic Archipelago. J. Geophys. Res. Oceans, 119, 3746-3766, https://doi.org/10.1002/2013JC009497.

_-, M. Levasseur, M. Scarratt, C. J. Mundy, M. Gosselin, R. P. Kiene, M. Gourdal1, and M. Lizotte, 2015: Under-ice microbial dimethylsulfoniopropionate metabolism during the melt period in the Canadian Arctic Archipelago. Mar. Ecol. Prog. Ser., 524, 39-53, https://doi.org/10.3354/meps11144.

— - and Coauthors, 2016: Contrasted sensitivity of DMSP production to high light exposure in two Arctic under-ice blooms. J. Exp. Mar. Biol. Ecol., 475, 38-48, https://doi.org/10.1016/j.jembe.2015.11.009.

Gosselin, M., M. Levasseur, P. A. Wheeler, R. A. Horner, and B. C. Booth, 1997: New measurements of phytoplankton and ice algal production in the Arctic Ocean. Deep-Sea Res. II, 44, 1623-1644, https://doi .org/10.1016/S0967-0645(97)00054-4.

Gradinger, R., 2009: Sea-ice algae: Major contributors to primary production and algal biomass in the Chukchi and Beaufort Seas during May/June 2002. Deep-Sea Res. II, 56, 1201-1212, https://doi.org/10.1016/j .dsr2.2008.10.016.

Hamacher-Barth, E., C. Leck, and K. Jansson, 2016: Size-resolved morphological properties of the high Arctic summer aerosol during ASCOS-2008. Atmos. Chem. Phys., 16, 6577-6593, https://doi.org/10.5194 /acp-16-6577-2016.

Heide-Jørgensen, M. P., K. L. Laidre, M. L. Logsdon, and T. G. Nielsen, 2007: Springtime coupling between chlorophyll $a$, sea ice and sea surface temperature in Disko Bay, West Greenland. Prog. Oceanogr., 73, 79-95, https://doi.org/10.1016/j.pocean.2007.01.006.

Heintzenberg, J., and C. Leck, 2012: The summer aerosol in the central Arctic 1991-2008: Did it change or not? Atmos. Chem. Phys., 12, 3969-3983, https://doi. org/10.5194/acp-12-3969-2012.

_ _ _ W. Birmili, B. Wehner, M. Tjernström, and A. Wiedensohler, 2006: Aerosol number-size distributions during clear and fog periods in the summer high Arctic: 1991, 1996 and 2001. Tellus, 58B, 41-50, https://doi.org/10.1111/j.1600-0889.2005.00171.x. 
,-- , and P. Tunved, 2015: Potential source regions and processes of aerosol in the summer Arctic. Atmos. Chem. Phys., 15, 6487-6502, https://doi.org /10.5194/acp-15-6487-2015.

Herber, A., and Coauthors, 2002: Continuous day and night aerosol optical depth observations in the Arctic between 1991 and 1999. J. Geophys. Res., 107, 4097, https://doi.org/10.1029/2001JD000536.

Hobbs, W. R., R. Massom, S. Stammerjohn, P. Reid, G. Williams, and W. Meier, 2016: A review of recent changes in Southern Ocean sea ice, their drivers and forcings. Global Planet. Change, 143, 228-250, https://doi.org/10.1016/j.gloplacha.2016.06.008.

Humphries, G. W., C. Deal, S. Elliott, and F. Huettmann, 2012: Spatial predictions of sea surface dimethylsulfide concentrations in the high Arctic. Biogeochemistry, 110, 287-301, https://doi.org/10.1007/s10533 -011-9683-y.

Humphries, R. S., A. R. Klekociuk, R. Schofield, M. Keywood, J. Ward, and S. R. Wilson, 2016: Unexpectedly high ultrafine aerosol concentrations above East Antarctic sea ice. Atmos. Chem. Phys., 16, 2185-2206, https://doi.org/10.5194/acp-16-2185-2016.

IPCC, 2013: Climate Change 2013: The Physical Science Basis. Cambridge University Press, 1535 pp., https:// doi.org/10.1017/CBO9781107415324.

Ito, A., and M. Kawamiya, 2010: Potential impact of ocean ecosystem changes due to global warming on marine organic carbon aerosols. Global Biogeochem. Cycles, 24, GB1012, https://doi.org/10.1029/2009GB003559.

Jones, G., D. Fortescue, S. King, G. Williams, and S. Wright, 2010: Dimethylsulphide and dimethylsulphoniopropionate in the south-west Indian Ocean sector of East Antarctica from $30^{\circ}$ to $80^{\circ} \mathrm{E}$ during BROKE-West. Deep-Sea Res. II, 57, 863-876, https:// doi.org/10.1016/j.dsr2.2009.01.003.

Karl, M., C. Leck, E. Coz, and J. Heintzenberg, 2013: Marine nanogels as a source of atmospheric nanoparticles in the high Arctic. Geophys. Res. Lett., 40, 3738-3743, https://doi.org/10.1002/grl.50661.

Kirst, G. O., C. Thiel, H. Wolff, J. Nothnagel, M. Wanzek, and R. Ulmke, 1991: Dimethylsulfoniopropionate (DMSP) in ice algae and its possible biological role. Mar. Chem., 35, 381-388, https://doi.org/10.1016 /S0304-4203(09)90030-5.

_- M. Wanzek, R. Haase, S. Rapsomanikis, S. Demora, G. Schebeske, and M. O. Andreae, 1993: Ecophysiology of ice algae (Antarctica): Dimethylsulphoniopropionate content and release of dimethylsulphide during ice melt. Proc. Int. Symp. Dimethylsulphide: Oceans, Atmosphere and Climate, Belgirate, Italy, Commission of the European Communities, 23-36.
Koga, S., D. Nomura, and M. Wada, 2014: Variation of dimethylsulfide mixing ratio over the Southern Ocean from $36^{\circ} \mathrm{S}$ to $70^{\circ} \mathrm{S}$. Polar Sci., 8, 306-313, https://doi.org/10.1016/j.polar.2014.04.002.

Korhonen, H., K. S. Carslaw, D. V. Spracklen, G. W. Mann, and M. T. Woodhouse, 2008: Influence of oceanic dimethyl sulfide emissions on cloud condensation nuclei concentrations and seasonality over the remote Southern Hemisphere oceans: A global model study. J. Geophys. Res., 113, D15204, https:// doi.org/10.1029/2007JD009718.

Leaitch, W. R., and Coauthors, 2013: Dimethyl sulfide control of the clean summertime Arctic aerosol and cloud. Elementa Sci. Anthropocene, 1, 17, https://doi .org/10.12952/journal.elementa.000017.

Leck, C., and C. Persson, 1996: The central Arctic Ocean as a source of dimethyl sulfide-Seasonal variability in relation to biological activity. Tellus, 48B, 156-177, https://doi.org/10.3402/tellusb.v48i2.15834.

— surface microlayer and overlaying atmosphere in the central Arctic Ocean during summer. Tellus, 57B, 305-316, https://doi.org/10.3402/tellusb.v57i4.16546.

- , and - 2005b: Source and evolution of the marine aerosol-A new perspective. Geophys. Res. Lett., 32, L19803, https://doi.org/10.1029/2005GL023651.

— , and E. Svensson, 2015: Importance of aerosol composition and mixing state for cloud droplet activation over the Arctic pack ice in summer. Atmos. Chem. Phys., 15, 2545-2568, https://doi.org/10.5194 lacp-15-2545-2015.

—, E. K. Bigg, D. S. Covert, J. Heintzenberg, W. Maenhaut, E. D. Nilsson, and A. Wiedensohler, 1996: Overview of the atmospheric research programme during the International Arctic Ocean Expedition of 1991 (IAOE91) and its scientific results. Tellus, 48B, 136-155, https://doi.org/10.3402/tellusb.v48i2.15833.

—, E. D. Nilsson, E. K. Bigg, and L. Backlin, 2001: Atmospheric program on the Arctic Ocean Expedition 1996 (AOE-96): An overview of scientific goals, experimental approach, and instruments. $J$. Geophys. Res., 106, 32 051-32 067, https://doi.org /10.1029/2000JD900461.

—, M. Tjernström, P. Matrai, E. Swietlicki, and K. Bigg, 2004: Can marine microorganisms influence melting of the Arctic pack ice? Eos, Trans. Amer. Geophys. Union, 85, 25-32, https://doi.org /10.1029/2004EO030001.

Legendre, L., and Coauthors, 1992: Ecology of sea ice biota. Polar Biol., 12, 429-444, https://doi.org/10.1007 /BF00243113.

Legrand, M., J. Sciare, B. Jourdain, and C. Genthon, 2001: Subdaily variations of atmospheric dimethylsulfide, 
dimethylsulfoxide, methanesulfonate, and non-seasalt sulfate aerosols in the atmospheric boundary layer at Dumont d'Urville (coastal Antarctica) during summer. J. Geophys. Res., 106, 14409-14422, https:// doi.org/10.1029/2000JD900840.

Leu, E., J. E. Soreide, D. O. Hessen, S. Falk-Petersen, and J. Berge, 2011: Consequences of changing sea-ice cover for primary and secondary producers in the European Arctic shelf seas: Timing, quantity, and quality. Prog. Oceanogr., 90, 18-32, https://doi.org /10.1016/j.pocean.2011.02.004.

Levasseur, M., 2013: Impact of Arctic meltdown on the microbial cycling of sulphur. Nat. Geosci., 6, 691-700, https://doi.org/10.1038/ngeo1910.

—, M. Gosselin, and S. Michaud, 1994: A new source of dimethyl sulfide for the Arctic atmosphere: Ice diatoms. Mar. Biol., 121, 381-387, https://doi .org/10.1007/BF00346748.

Liss, P. S., W. J. Broadgate, A. D. Hatton, R. H. Little, G. Malin, N. C. McArdle, P. D. Nightingale, and S. M. Turner, 2000: Biological production of trace gases in surface sea water and their emission to the atmosphere. Exchange and Transport of Air Pollutants over Complex Terrain and the Sea, S. Larsen, F. Fiedler, and P. Borrell, Eds., Springer, 139-144, https://doi .org/10.1007/978-3-642-57252-4_18.

Liu, J., J. A. Curry, H. Wang, M. Song, and R. M. Horton, 2012: Impact of declining Arctic sea ice on winter snowfall. Proc. Natl. Acad. Sci. USA, 109, 4074-4079, https://doi.org/10.1073/pnas.1114910109.

Lundén, J., G. Svensson, and C. Leck, 2007: Influence of meteorological processes on the spatial and temporal variability of atmospheric dimethyl sulfide in the high Arctic summer. J. Geophys. Res., 112, D13308, https://doi.org/10.1029/2006JD008183.

Maslanik, J., J. Stroeve, C. Fowler, and W. Emery, 2011: Distribution and trends in Arctic sea ice age through spring 2011. Geophys. Res. Lett., 38, L13502, https:// doi.org/10.1029/2011GL047735.

Massonnet, F., V. Guemas, N. S. Fučkar, and F. J. DoblasReyes, 2015: The 2014 high record of Antarctic sea ice extent [in "Explaining Extreme Events of 2014 from a Climate Perspective"]. Bull. Amer. Meteor. Soc., 96 (12), S163-S167, https://doi.org/10.1175/ BAMS-D-15-00093.1.

Matrai, P. A., and M. Vernet, 1997: Dynamics of the vernal bloom in the marginal ice zone of the Barents Sea: Dimethyl sulfide and dimethylsulfoniopropionate budgets. J. Geophys. Res., 102, 22 965-22 979, https:// doi.org/10.1029/96JC03870.

—_ — - and P. Wassmann, 2007: Relating temporal and spatial patterns of DMSP in the Barents Sea to phytoplankton biomass and productivity. J. Mar.
Syst., 67, 83-101, https://doi.org/10.1016/j.jmarsys .2006.10.001.

McCoy, D. T., S. M. Burrows, R. Wood, D. P. Grosvenor, S. M. Elliott, P.-L. Ma, P. J. Rasch, and D. L. Hartmann, 2015: Natural aerosols explain seasonal and spatial patterns of Southern Ocean cloud albedo. Sci. Adv., 1, e1500157, https://doi.org/10.1126 /sciadv.1500157.

McMinn, A., M. N. Müller, A. Martin, and K. G. Ryan, 2014: The response of Antarctic sea ice algae to changes in $\mathrm{pH}$ and $\mathrm{CO}_{2}$. PLoS One, 9, e86984, https:// doi.org/10.1371/journal.pone.0086984.

Moreau, S., B. Mostajir, S. Bélanger, I. R. Schloss, M. Vancoppenolle, S. Demers, and G. A. Ferreyra, 2015: Climate change enhances primary production in the western Antarctic Peninsula. Global Change Biol., 21, 2191-2205, https://doi.org/10.1111/gcb.12878.

Mungall, E. L., and Coauthors, 2016: Dimethyl sulfide in the summertime Arctic atmosphere: Measurements and source sensitivity simulations. Atmos. Chem. Phys., 16, 6665-6680, https://doi.org/10.5194 /acp-16-6665-2016.

NationalSnowand Ice Data Center,2016:2016ties with 2007 for second lowest Arctic sea ice minimum. Accessed 22 September 2016, http://nsidc.org/arcticseaicenews /2016/09/2016-ties-with-2007-for-second-lowest -arctic-sea-ice-minimum/.

Nomura, D., N. Kasamatsu, K. Tateyama, S. Kudoh, and M. Fukuchi, 2011: DMSP and DMS in coastal fast ice and under-ice water of Lützow-Holm Bay, eastern Antarctica. Cont. Shelf Res., 31, 1377-1383, https:// doi.org/10.1016/j.csr.2011.05.017.

O'Dowd, C. D., M. H. Smith, I. E. Consterdine, and J. A. Lowe, 1997: Marine aerosol, sea-salt, and the marine sulphur cycle: A short review. Atmos. Environ., 31, 73-80, https://doi.org/10.1016/S1352-2310(96)00106-9.

Orellana, M. V., P. A. Matrai, C. Leck, C. D. Rauschenberg, A. M. Lee, and E. Coz, 2011: Marine microgels as a source of cloud condensation nuclei in the high Arctic. Proc. Natl. Acad. Sci. USA, 108, 13612-13617, https://doi.org/10.1073/pnas.1102457108.

Overland, J. E., and M. Wang, 2013: When will the summer Arctic be nearly sea ice free? Geophys. Res. Lett., 40, 2097-2101, https://doi.org/10.1002/grl.50316.

Park, K.-T., and Coauthors, 2013: Linking atmospheric dimethyl sulfide and the Arctic Ocean spring bloom. Geophys. Res. Lett., 40, 155-160, https://doi .org/10.1029/2012GL054560.

Parkinson, C. L., and D. J. Cavalieri, 2012: Antarctic sea ice variability and trends, 1979-2010. Cryosphere, 6, 871-880, https://doi.org/10.5194/tc-6-871-2012.

— , and J. C. Comiso, 2013: On the 2012 record low Arctic sea ice cover: Combined impact of preconditioning 
and an August storm. Geophys. Res. Lett., 40, 13561361, https://doi.org/10.1002/grl.50349.

Parmentier, F.-J. W., T. R. Christensen, L. L. Sørensen, S. Rysgaard, A. D. McGuire, P. A. Miller, and D. A. Walker, 2013: The impact of lower sea-ice extent on Arctic greenhouse-gas exchange. Nat. Climate Change, 3, 195-202, https://doi.org/10.1038/nclimate 1784.

Quinn, P. K., G. Shaw, E. Andrews, E. G. Dutton, T. Ruoho-Airola, and S. L. Gong, 2007: Arctic haze: Current trends and knowledge gaps. Tellus, 59B, 99-114, https://doi.org/10.1111/j.1600-0889 .2006.00236.x.

—, T. S. Bates, K. Schulz, and G. E. Shaw, 2009: Decadal trends in aerosol chemical composition at Barrow, Alaska: 1976-2008. Atmos. Chem. Phys., 9, 8883-8888, https://doi.org/10.5194/acp-9-8883-2009.

Remer, L. A., and Coauthors, 2008: Global aerosol climatology from the MODIS satellite sensors. J. Geophys. Res., 113, D14S07, https://doi.org/10.1029/2007jd009661.

Rempillo, O., and Coauthors, 2011: Dimethyl sulfide airsea fluxes and biogenic sulfur as a source of new aerosols in the Arctic fall. J. Geophys. Res., 116, D00S04, https://doi.org/10.1029/2011JD016336.

Saba, G. K., and Coauthors, 2014: Winter and spring controls on the summer food web of the coastal West Antarctic Peninsula. Nat. Commun., 5, 4318, https:// doi.org/10.1038/ncomms5318.

Sabu, P., N. Anilkumar, J. V. George, R. Chacko, S. C. Tripathy, and C. T. Achuthankutty, 2014: The influence of air-sea-ice interactions on an anomalous phytoplankton bloom in the Indian Ocean sector of the Antarctic Zone of the Southern Ocean during the austral summer, 2011. Polar Sci., 8, 370-384, https:// doi.org/10.1016/j.polar.2014.08.001.

Saenz, B. T., and K. R. Arrigo, 2014: Annual primary production in Antarctic sea ice during 2005-2006 from a sea ice state estimate. J. Geophys. Res. Oceans, $\mathbf{1 1 9}$, 3645-3678, https://doi.org/10.1002/2013JC009677.

Screen, J. A., and I. Simmonds, 2010: The central role of diminishing sea ice in recent Arctic temperature amplification. Nature, 464, 1334-1337, https://doi.org /10.1038/nature09051.

Serreze, M. C., and R. G. Barry, 2011: Processes and impacts of Arctic amplification: A research synthesis. Global Planet. Change, 77, 85-96, https://doi .org/10.1016/j.gloplacha.2011.03.004.

_ , M. M. Holland, and J. Stroeve, 2007: Perspectives on the Arctic's shrinking sea-ice cover. Science, 315, 1533-1536, https://doi.org/10.1126/science.1139426.

Sharma, S., L. A. Barrie, D. Plummer, J. C. McConnell, P. C. Brickell, M. Levasseur, M. Gosselin, and T. S. Bates, 1999: Flux estimation of oceanic dimethyl sulfide around North America. J. Geophys. Res., 104, $21327-21342$, https://doi.org/10.1029/1999JD900207.

— , and Coauthors, 2012: Influence of transport and ocean ice extent on biogenic aerosol sulfur in the Arctic atmosphere. J. Geophys. Res., 117, D12209, https:// doi.org/10.1029/2011JD017074.

Shu, Q., Z. Song, and F. Qiao, 2015: Assessment of sea ice simulations in the CMIP5 models. Cryosphere, 9, 399-409, https://doi.org/10.5194/tc-9-399-2015.

Simmonds, I., 2015: Comparing and contrasting the behaviour of Arctic and Antarctic sea ice over the 35 year period 1979-2013. Ann. Glaciol., 56, 18-28, https://doi.org/10.3189/2015AoG69A909.

Simó, R., 2001: Production of atmospheric sulfur by oceanic plankton: Biogeochemical, ecological and evolutionary links. Trends Ecol. Evol., 16, 287-294, https://doi.org/10.1016/S0169-5347(01)02152-8.

Sirois, A., and L. A. Barrie, 1999: Arctic lower tropospheric aerosol trends and composition at Alert, Canada: 1980-1995. J. Geophys. Res., 104, 11 599-11 618, https://doi.org/10.1029/1999JD900077.

Six, K. D., S. Kloster, T. Ilyina, S. D. Archer, K. Zhang, and E. Maier-Reimer, 2013: Global warming amplified by reduced sulphur fluxes as a result of ocean acidification. Nat. Climate Change, 3, 975-978, https://doi .org/10.1038/nclimate1981.

Stammerjohn, S. E., D. G. Martinson, R. C. Smith, and R. A. Iannuzzi, 2008: Sea ice in the western Antarctic Peninsula region: Spatio-temporal variability from ecological and climate change perspectives. DeepSea Res. II, 55, 2041-2058, https://doi.org/10.1016/j .dsr2.2008.04.026.

—, R. Massom, D. Rind, and D. Martinson, 2012: Regions of rapid sea ice change: An inter-hemispheric seasonal comparison. Geophys. Res. Lett., 39, L06501, https://doi.org/10.1029/2012gl050874.

Steiner, N., and Coauthors, 2015: Observed trends and climate projections affecting marine ecosystems in the Canadian Arctic. Environ. Rev., 23, 191-239, https://doi .org/10.1139/er-2014-0066.

Stewart, F. J., and C. H. Fritsen, 2004: Bacteria-algae relationships in Antarctic sea ice. Antarct. Sci., 16, 143-156, https://doi.org/10.1017/S0954102004001889.

Stohl, A., 2006: Characteristics of atmospheric transport into the Arctic troposphere. J. Geophys. Res., 111, D11306, https://doi.org/10.1029/2005JD006888.

Stroeve, J., M. M. Holland, W. Meier, T. Scambos, and M. Serreze, 2007: Arctic sea ice decline: Faster than forecast. Geophys. Res. Lett., 34, L09501, https://doi .org/10.1029/2007GL029703.

Struthers, H., A. M. L. Ekman, P. Glantz, T. Iversen, A. Kirkevåg, E. M. Mårtensson, Ø. Seland, and E. D. Nilsson, 2011: The effect of sea ice loss on sea salt 
aerosol concentrations and the radiative balance in the Arctic. Atmos. Chem. Phys., 11, 3459-3477, https://doi.org/10.5194/acp-11-3459-2011.

Thoisen, C., K. Riisgaard, N. Lundholm, T. G. Nielsen, and P. J. Hansen, 2015: Effect of acidification on an Arctic phytoplankton community from Disko Bay, west Greenland. Mar. Ecol. Prog. Ser., 520, 21-34, https://doi.org/10.3354/meps11123.

Tison, J.-L., F. Brabant, I. Dumont, and J. Stefels, 2010: High-resolution dimethyl sulfide and dimethylsulfoniopropionate time series profiles in decaying summer first-year sea ice at Ice Station Polarstern, western Weddell Sea, Antarctica. J. Geophys. Res., 115, G04044, https://doi.org/10.1029/2010jg001427.

Tjernström, M., C. Leck, P. O. G. Persson, and M. L. Jensen, 2004: The summertime Arctic atmosphere: Meteorological measurements during the Arctic Ocean Experiment 2001. Bull. Amer. Meteor. Soc., 85, 1305-1321, https://doi.org/10.1175/BAMS-85 -9-1305.

- , and Coauthors, 2014: The Arctic Summer Cloud Ocean Study (ASCOS): Overview and experimental design. Atmos. Chem. Phys., 14, 2823-2869, https:// doi.org/10.5194/acp-14-2823-2014.

Toth, T. D., and Coauthors, 2013: Investigating enhanced Aqua MODIS aerosol optical depth retrievals over the mid-to-high latitude Southern Oceans through intercomparison with co-located CALIOP, MAN, and AERONET data sets. J. Geophys. Res. Atmos., 118, 4700-4714, https://doi.org/10.1002/jgrd.50311.

Tremblay, J.-É., L. G. Anderson, P. Matrai, P. Coupel, S. Bélanger, C. Michel, and M. Reigstad, 2015: Global and regional drivers of nutrient supply, primary production and $\mathrm{CO}_{2}$ drawdown in the changing Arctic Ocean. Prog. Oceanogr., 139, 171-196, https://doi .org/10.1016/j.pocean.2015.08.009.

Trevena, A. J., and G. B. Jones, 2006: Dimethylsulphide and dimethylsulphoniopropionate in Antarctic sea ice and their release during sea ice melting. Mar. Chem., 98, 210-222, https://doi.org/10.1016/j.marchem .2005 .09 .005 .
— , and — 2012: DMS flux over the Antarctic sea ice zone. Mar. Chem., 134, 47-58, https://doi.org/10.1016 /j.marchem.2012.03.001.

$\longrightarrow,-$, S. W. Wright, and R. L. van den Enden, 2003: Profiles of dimethylsulphoniopropionate (DMSP), algal pigments, nutrients, and salinity in the fast ice of Prydz Bay, Antarctica. J. Geophys. Res., 108, 3145, https://doi.org/10.1029/2002JC001369.

Vallina, S. M., R. Simó, and S. Gassó, 2006: What controls CCN seasonality in the Southern Ocean? A statistical analysis based on satellite-derived chlorophyll and $\mathrm{CCN}$ and model-estimated $\mathrm{OH}$ radical and rainfall. Global Biogeochem. Cycles, 20, GB1014, https://doi.org/10.1029/2005GB002597.

Vance, T. R., A. T. Davidson, P. G. Thomson, M. Levasseur, M. Lizotte, M. A. Curran, and G. B. Jones, 2013: Rapid DMSP production by an Antarctic phytoplankton community exposed to natural surface irradiances in late spring. Aquat. Microb. Ecol., 71, 117-129, https:// doi.org/10.3354/ame01670.

Ye, P., Z. Xie, J. Yu, and H. Kang, 2015: Spatial distribution of methanesulphonic acid in the Arctic aerosol collected during the Chinese Arctic Research Expedition. Atmosphere, 6, 699-712, https://doi.org/10.3390 /atmos6050699.

Zemmelink, H. J., L. Houghton, J. W. H. Dacey, A. P. Worby, and P. S. Liss, 2005: Emission of dimethylsulfide from Weddell Sea leads. Geophys. Res. Lett., 32, L23610, https://doi.org/10.1029/2005GL024242.

_ J. W. H. Dacey, L. Houghton, E. J. Hintsa, and P. S. Liss, 2008: Dimethylsulfide emissions over the multiyear ice of the western Weddell Sea. Geophys. Res. Lett., 35, L06603, https://doi.org/10.1029/2007gl031847.

Zwally, H. J., C. L. Parkinson, and J. C. Comiso, 1983: Variability of Antarctic sea ice and changes in carbon dioxide. Science, 220, 1005-1012, https://doi .org/10.1126/science.220.4601.1005.

—, J. C. Comiso, C. L. Parkinson, D. J. Cavalieri, and P. Gloersen, 2002: Variability of Antarctic sea ice 1979-1998. J. Geophys. Res., 107, 3041, https://doi .org/10.1029/2000JC000733. 


\section{Find out from the authoritative source}

[ What's a dust devil? ]

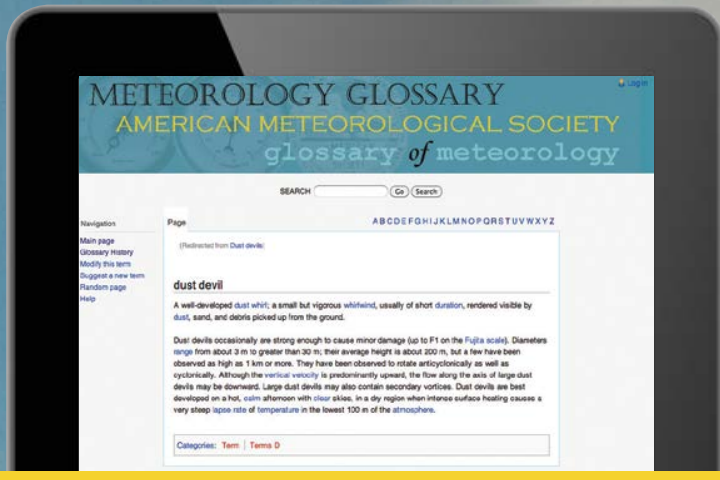

THE A M E R I C A N M E TEOROLO G I C A L S O I E T Y

\section{Online Glossary of Meteorology}

With over 12,000 meteorological terms, you'll be able to look up definitions online any time, any place, anywhere. http://glossary.ametsoc.org/wiki 